\title{
Epigenetic Regulation of Auxin-Induced Somatic Embryogenesis in Plants
}

\author{
Barbara Wójcikowska *(D), Anna M. Wójcik ${ }^{\circledR}$ and Małgorzata D. Gaj ${ }^{(1)}$ \\ Institute of Biology, Biotechnology and Environmental Protection, Faculty of Natural Sciences, University of \\ Silesia in Katowice, Jagiellońska 28, 40-032 Katowice, Poland; anna.wojcik@us.edu.pl (A.M.W.); \\ malgorzata.gaj@us.edu.pl (M.D.G.) \\ * Correspondence: barbara.wojcikowska@us.edu.pl; Tel.: +48-32-2009-428
}

Received: 5 February 2020; Accepted: 24 March 2020; Published: 26 March 2020

\begin{abstract}
Somatic embryogenesis (SE) that is induced in plant explants in response to auxin treatment is closely associated with an extensive genetic reprogramming of the cell transcriptome. The significant modulation of the gene transcription profiles during SE induction results from the epigenetic factors that fine-tune the gene expression towards embryogenic development. Among these factors, microRNA molecules (miRNAs) contribute to the post-transcriptional regulation of gene expression. In the past few years, several miRNAs that regulate the SE-involved transcription factors (TFs) have been identified, and most of them were involved in the auxin-related processes, including auxin metabolism and signaling. In addition to miRNAs, chemical modifications of DNA and chromatin, in particular the methylation of DNA and histones and histone acetylation, have been shown to shape the SE transcriptomes. In response to auxin, these epigenetic modifications regulate the chromatin structure, and hence essentially contribute to the control of gene expression during SE induction. In this paper, we describe the current state of knowledge with regard to the SE epigenome. The complex interactions within and between the epigenetic factors, the key SE TFs that have been revealed, and the relationships between the SE epigenome and auxin-related processes such as auxin perception, metabolism, and signaling are highlighted.
\end{abstract}

Keywords: auxin; DNA methylation; epigenetics; histone modifications; MIRNA genes; somatic embryogenesis

\section{Introduction}

Since its discovery in the late 1950s, somatic embryogenesis (SE) is widely used for commercial plant micropropagation and transgenic plant production in plant biotechnology (reviewed in [1]). In addition to its practical value, SE provides a unique research system for studies on the molecular mechanisms that govern the developmental plasticity in plants [2]. The molecular pathways involved in the embryogenic response of in vitro-cultured plant explants are of particular interest in plant developmental biology because studies on SE contribute to the understanding of the regulatory mechanisms controlling toti- and pluripotency in plant somatic cells.

$\mathrm{SE}$ is induced by the transcriptomic reprogramming of the somatic plant cells that response to an induction signal, mostly after auxin treatment, and enter the embryogenic pathway of development and form embryo-like structures, the so-called somatic embryos. A great deal of the progress that has been achieved in the deciphering of the SE-regulatory network in recent years is attributed to the outcomes from studies on SE in Arabidopsis, a model in plant molecular genetics and genomics [3]. In Arabidopsis and numerous other plants, auxin treatment is the most efficient inducer of the embryogenic response in the in vitro cultured explants [4,5]. Similarly, auxin is a highly potent signaling molecule that controls almost every aspect of development in planta, including the promotion of cell division and elongation, 
root, leaf, flower, zygotic embryo, and fruit development [6-8]. A basic mechanism by which auxin triggers diverse developmental processes includes regulation of gene expression at the transcriptional level through the auxin signaling pathway and the core components of this pathway include the TRANSPORT INHIBITOR RESISTANT1/AUXIN SIGNALING F-BOX (TIR1/AFB) F-box proteins, the AUXIN/INDOLE-3-ACETIC ACID (Aux/IAA) transcriptional coregulators, and sequence-specific binding proteins called AUXIN RESPONSE FACTORs (ARFs) [9]. However, to understand the huge versatility of auxin-mediated developmental responses, crosstalk of auxin with epigenetic processes needs to be considered (Figure 1). In support of this approach, an increasing number of studies have suggested a close link between the auxin and epigenetic regulation of gene expression through miRNAs and chromatin modifications [10-12]. Consistently, the impact of miRNA regulation on auxin responses was evidenced, and specific miRNAs controlling the core elements of the auxin signaling pathway, including ARF, AUX/IAA, and TIR1/AFB receptors were identified [10,13].

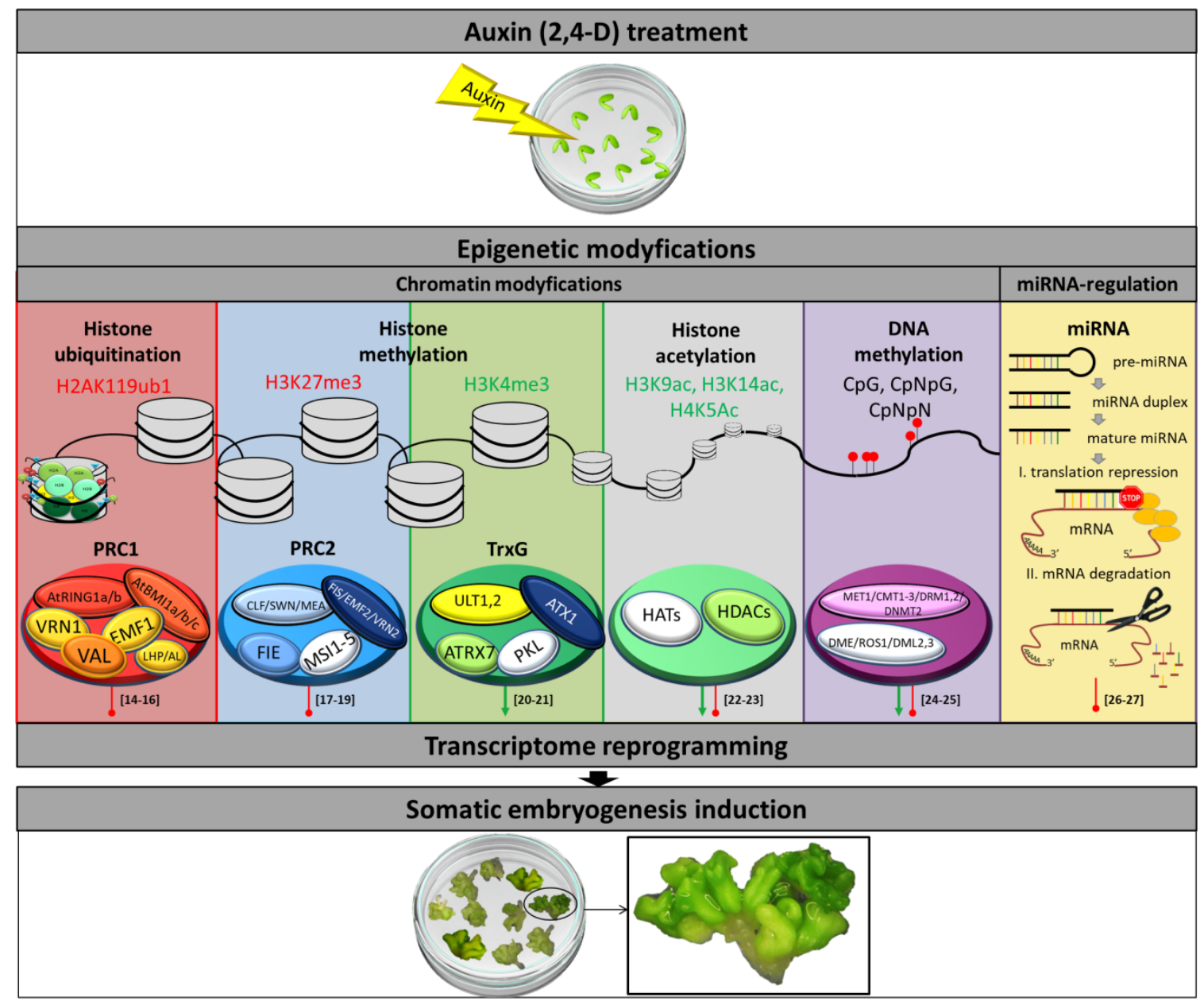

Figure 1. An overview of the epigenetic processes, including chromatin modifications and miRNAmediated gene regulation that control auxin-induced embryogenic response of explant cells. Modifications of chromatin, including histone methylation, acetylation, and ubiquitination together with DNA methylation, control the transcriptome of explant cells in response to auxin treatment. The epigenetic complexes controlling the SE-transcriptome involve both the repressors (PRC1, PRC2, HDACs, DRM1-2, MET1, CMT1-3, and DNMT2) and activators (TrxG, HATs, DME, ROS1, and DML2-3) of gene expression. The specific epigenetic marks that activate and repress gene transcription are indicated in green and red, respectively. Arrows and circle-shaped ends show the activation or repression of gene expression, respectively [14-27]. (2,4-D) 2,4-dichlorophenoxyacetic acid; (AL) ALFIN-LIKE; (AtBMI1a/b/c) B LYMPHOMA Mo-MLV INSERTION REGION 1 HOMOLOGa/b/c; (AtRING1a/b) RING FINGER PROTEIN1a/b; (ATRX7) Arabidopsis TRITHORAX-RELATED7; (ATX1) ARABIDOPSIS HOMOLOG 
OF TRITHORAX1; (CLF) CURLY LEAF; (CMT1-3) CHROMOMETHYLASE1-3; (DME) DEMETER; (DML2,3) DEMETER-LIKE PROTEIN2,3; (DNMT2) DNA NUCLEOTIDE METHYLTRANSFERASE2; (DRM1,2) DOMAINS REARRANGED METHYLTRANSFERASE1,2; (EMF1,2) EMBRYONIC FLOWER1,2; (FIE) FERTILIZATION-INDEPENDENT ENDOSPERM; (FIS) FERTILIZATION INDEPENDENT SEED; (HATs) HISTONE ACETYLTRANSFERASEs; (HDACs) HISTONE DEACETYLASEs; (LHP) LIKE HETEROCHROMATIN PROTEIN; (MEA) MEDEA; (MET1) METHYLTRANSFERASE1; (miRNA) microRNA; (MSI1-5) MULTICOPY SUPPRESSOR OF IRA1-5; (PKL) PICKLE; (PRC1,2) POLYCOMB REPRESSIVE COMPLEX1,2; (ROS1) REPRESSOR OF SILENCING1; (SWN) SWINGER; (TrxG) Trithoraxgroup; (ULT1,2) ULTRAPETALA1,2; (VAL) VP1/ABI3-LIKE1-3; (VRN1,2) VERNALIZATION1,2.

miRNAs, which are products of the MIRNA genes, are small (19 to 24 nucleotides long), single-stranded non-coding RNA molecules that regulate both the state of the chromatin-associated with their targets and the availability of the encoded transcripts for protein translation [26]. Plant miRNAs have a high sequence specificity to their targets, and they tend to have fewer targets as compared with animal miRNAs [27]. Since their discovery in 2002 [28], plant miRNAs have been found to control many aspects of plant development, including their developmental plasticity and auxin responses $[29,30]$. During plant development, miRNAs preferentially target the genes that have a regulatory function, including those encoding transcription factors (TFs) and F-box proteins [31,32].

Auxin-mediated regulation of gene expression also involves the interplay of auxin with epigenetic modifications of DNA and histones, the processes of a pivotal role in controlling the development processes in animals and plants (reviewed by [33,34]). Methylation of DNA is the most intensively studied epigenetic mechanism that controls gene expression [35-37]. The methylation of plant DNA involves the addition of a methyl group to the carbon- 5 of cytosine at the $\mathrm{CpG}, \mathrm{CpNpG}$, and $\mathrm{CpNpN}$ (N-any nucleotide except for $\mathrm{G}$ ) sequences in DNA, which increases the content of 5-methyl cytosine $(5 \mathrm{mC})$ in the genome. The impact of DNA methylation on gene transcription has been widely evidenced, and the effect of $5 \mathrm{mC}$ depends on the gene region (promotor $(\mathrm{P})$ vs. the gene body $(\mathrm{GB})$ ) that is to be methylated. Accordingly, the methylation of the gene promotor usually results in the repression of gene transcription, while an accumulation of $5 \mathrm{mC}$ in the GB is frequently associated with the constitutively expressed housekeeping genes [38]. Moreover, GB methylation seems to contribute to the regulation of the gene responses to internal or external cues [39]. The heterochromatin regions, imprinted genes, repetitive sequences, and transposons [40] display a high methylation level. In histone methylation, methyl groups are transferred to amino acid residues, mostly lysine, and the process is dynamically catalyzed by histone methylases and demethylases [41]. Depending on the target lysine and the degree of methylation, activation, or inactivation of genes could be induced [42]. The most frequent histone methylation marks, H3K27me3 and H3K4me3, are catalyzed by, respectively, the Polycomb-group (PcG) and Trithorax-group (TrxG) proteins, of documented roles in regulating plant developmental plasticity, including stem cell maintenance, cellular reprogramming, and plant responses to environmental cues (reviewed in [20], [43]). The PcG proteins are classified into two complexes, POLYCOMB REPRESSIVE COMPLEX 1 and 2 (PRC1 and PRC2), which cooperate to repress the genes via histone methylation during plant development [44]. The PRC2 of histone methyltransferase activity establishes the H3K27me3 markers to which the PRC1 complex binds and monoubiquitinates H2A histones (H2AK119ub1) in order to continually silence the transcription of a given genomic region [45]. A significant number (27.6\%) of protein- and miRNA-coding genes in Arabidopsis have been found to be targeted by the H3K27me3 marker, which confirms the importance of the PRC-mediated gene silencing in plants [17]. Distinct PcG complexes exist in Arabidopsis, which differ in composition and function in plant development, and several protein members of the PRC2 and PRC1 complexes have been identified [20].

In histone acetylation, lysine residues on the N-terminal tails of histones undergo acetylation that results in weakening of the histone-histone and histone-DNA interactions, and in turn, the DNA accessibility to the chromatin-binding proteins is increased [46]. The dynamic changes in the state of 
histone acetylation is controlled by antagonistically acting enzymes, histone acetyltransferases (HATs), and histone deacetylases (HDACs) [47] and the interplay between the HAT and HDAC regulates developmental processes and stress responses (reviewed by [48,49]). The acetylation of histones is believed to promote open chromatin state and activate gene transcription [50].

To regulate gene expression in plant development, different epigenetic modifications, including DNA methylation and histone methylation and acetylation, extensively interplay following complex mutual interactions [51]. Insights into the methylome of numerous Arabidopsis mutants confirmed the complex regulatory pathways that mutually control DNA and histone methylation [52]. For example, the methylation of histone 3 at the K9 site was implicated in the regulation of DNA methylation in such a way that the SUVR2-conserved factor that is required for H3K9 methylation regulates the DOMAINS REARRANGED METHYLTRANSFERASE2 (DRM2) pathway of DNA methylation [52].

Numerous TF genes of auxin-related functions have been identified to control SE induction, and the complex regulatory interactions between the genetic regulators of SE have been evidenced [53]. However, to reveal the entire SE-regulatory network, epigenetic processes that orchestrate somatic cell transcriptome in response to the induction signal (mostly auxin) need to be explored. Here, we review the current state of knowledge about epigenetic regulation of SE induction and the evidence suggesting a role of miRNAs, DNA methylation, and histone modifications via acetylation and methylation, in SE induction, is reported.

\section{Auxin-Related miRNAs Fine-Tune the Genetic Network that Controls SE}

Extensive modulation of the TF genes in an embryogenic culture of Arabidopsis is accompanied by differential expression of numerous miRNAs, suggesting the function of miRNA-regulation in the embryogenic transition of plant somatic cells [54,55]. In support, the $d c l 1$ mutant, a defect in the DICERLIKE1 (DCL1) gene with a key role in miRNA biogenesis, was shown to be unable for $\mathrm{SE}$ induction [56]. In addition to Arabidopsis, numerous miRNAs with a differential expression have been identified in embryogenic cultures of different gymnosperm, mono- and dicot plants, including economically important species [57-77]. A significant part of the SE-associated miRNAs comprises the auxin-related miRNAs whose target genes are engaged in auxin perception, signaling, and biosynthesis (Table 1). The auxin-related miRNAs frequently represented in embryogenic cultures involve miR165/166 and miR167 found in all of the analyzed SE systems: miR160, miR164, and miR390 identified in the majority of the SE-transcriptomes (77\% to $92 \%$ ), and miR393 expressed in some of the embryogenic cultures.

Transcriptomic datasets on Zea mays embryogenic cultures have shown that the expression pattern of individual auxin-related miRNAs is dependent on the genotype and the age of a culture [66-68,78]. The diversity of the miRNA expression profiles in embryogenic cultures, for example, the up- vs. downregulation of the same miRNA, could reflect the complexity of the miRNA-mediated regulatory pathways that fine-tune the somatic cell transcriptome towards embryogenic development in response to specific endo- and exogenous culture factors.

Numerous MIRNA genes, including members of the same gene family of SE-modulated expression, have been reported in transcriptomic analyses of different plant cultures $[55,58,66,68,73,79]$. The expression of different MIRNA gene family members is strictly regulated during plant development in an organ- and tissue-specific manner [80,81], and thus reporter line analyses could be important in identifying the specific MIRNA genes that contribute to SE induction. Accordingly, the expression of MIR167c, MIR393a,b, and MIR396b have been found to colocalize with the SE-induction sites of the explants, which supports the contribution of these genes to miRNA-mediated regulation of SE $[56,82,83]$. However, most of the reporter lines monitor the gene promoter activity rather than localize the corresponding gene transcript. Hence, a novel method of the whole-mount in situ hybridization (WISH) was recently proposed to analyze the spatiotemporal pattern of miRNAs in SE-induced tissue [84]. 
Table 1. The miRNA molecules involved in auxin perception, signaling, and biosynthesis expressed in the SE transcriptomes of different plants [85-90]. x, transcriptomic analysis; $\bullet$, functional analysis.

\begin{tabular}{|c|c|c|c|c|c|c|c|c|}
\hline \multirow{2}{*}{\multicolumn{2}{|c|}{ miRNA Name }} & \multirow{2}{*}{$\begin{array}{c}\text { AUXIN } \\
\text { PERCEPTION } \\
\text { miR393 } \\
\end{array}$} & \multicolumn{3}{|c|}{ AUXIN SIGNALING } & \multicolumn{2}{|c|}{$\begin{array}{c}\text { AUXIN } \\
\text { BIOSYNTHESIS }\end{array}$} & \multirow{2}{*}{$\begin{array}{c}\text { OTHER } \\
\text { miR164 }\end{array}$} \\
\hline & & & $\operatorname{miR} 160$ & $\operatorname{miR} 167$ & $\operatorname{miR} 390$ & $\operatorname{miR} 165 / 166$ & miR396 & \\
\hline \multicolumn{2}{|c|}{ Target genes } & $\begin{array}{l}\text { TIR1, AFB1, } \\
A F B 2, A F B 3\end{array}$ & $\begin{array}{l}\text { ARF10, } \\
\text { ARF16, } \\
\text { ARF17 }\end{array}$ & $\begin{array}{l}\text { ARF6, } \\
\text { ARF8 }\end{array}$ & $\begin{array}{l}\text { TAS3, } \\
\text { ARF2, } \\
\text { ARF3, } \\
\text { ARF4, } \\
\text { ARF5 }\end{array}$ & $\begin{array}{c}\text { PHB, PHV, } \\
\text { HDZ31, } \\
\text { HDZ32, } \\
\text { HDZ33 }\end{array}$ & GRFs & $\begin{array}{l}\text { NAC1, } \\
\text { CUC1, } \\
\text { CUC2 }\end{array}$ \\
\hline \multirow{13}{*}{ SPECIES } & A. thaliana & $\bullet x$ & $\bullet x$ & $\bullet x$ & $\mathrm{x}$ & - $x$ & $\bullet x$ & $\mathrm{x}$ \\
\hline & Z. mays & $\mathrm{x}$ & $\mathrm{x}$ & $\mathrm{x}$ & $\mathrm{x}$ & $\mathrm{x}$ & $\mathrm{x}$ & $\mathrm{x}$ \\
\hline & C. sinensis & $\mathrm{x}$ & $\mathrm{x}$ & $\mathrm{x}$ & $\mathrm{x}$ & $\mathrm{x}$ & $\mathrm{x}$ & $\mathrm{x}$ \\
\hline & D. longan & $x$ & $x$ & $\mathrm{x}$ & $x$ & $x$ & & $x$ \\
\hline & G. hirsutum & $\mathrm{x}$ & $\mathrm{x}$ & $\mathrm{x}$ & $\mathrm{x}$ & $\mathrm{x}$ & $\mathrm{x}$ & $\mathrm{x}$ \\
\hline & L. leptolepis & & $\mathrm{x}$ & $\mathrm{x}$ & $x$ & $\cdot x$ & $x$ & $x$ \\
\hline & L. pomilum & & $\mathrm{x}$ & $\mathrm{x}$ & $x$ & $\mathrm{x}$ & $\mathrm{x}$ & $x$ \\
\hline & $\begin{array}{l}\text { L. tulipiferax } \\
\text { L. chinense } \\
\end{array}$ & & $\mathrm{x}$ & $\mathrm{x}$ & $\mathrm{x}$ & $\mathrm{x}$ & $\mathrm{x}$ & $\mathrm{x}$ \\
\hline & T. aestivum & $\mathrm{x}$ & & $\mathrm{x}$ & & $x$ & $\mathrm{x}$ & $x$ \\
\hline & P. balfouriana & & $\mathrm{x}$ & $\mathrm{x}$ & $x$ & $\mathrm{x}$ & $x$ & $x$ \\
\hline & O. sativa & & & $\mathrm{x}$ & & $x$ & & $x$ \\
\hline & C. nucifera & & & $\mathrm{x}$ & & $\mathrm{x}$ & & $\mathrm{x}$ \\
\hline & P. pinaster & & $\mathrm{x}$ & $x$ & $\mathrm{x}$ & $x$ & $\mathrm{x}$ & \\
\hline \multicolumn{2}{|c|}{ References } & $\begin{array}{c}{[55,61,63,65,} \\
70-73,88]\end{array}$ & $\begin{array}{r}{[55,61-} \\
65,68,71, \\
73,75,78, \\
79,82,85]\end{array}$ & $\begin{array}{c}\text { [55-58, } \\
61-65,67, \\
71,74,75, \\
78,82,85, \\
89,90]\end{array}$ & $\begin{array}{c}{[55,57,58,} \\
61-63,65, \\
66,71,75, \\
78,82,85]\end{array}$ & 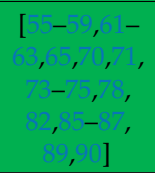 & $\begin{array}{c}{[55,59,61} \\
65,67,69- \\
72,75,78, \\
79,83]\end{array}$ & $\begin{array}{c}{[55,57,58,} \\
61-63,69- \\
71,73,74,78, \\
79,85,89]\end{array}$ \\
\hline
\end{tabular}

In addition, an analysis of the STTM (short target tandem mimic) and MIM (artificial miRNA target mimic) lines with a deregulated expression of MIRNA genes and miRNA targets [91,92] provided a powerful tool for identifying the miRNA function in plant development including SE induction. It was shown that a deregulated expression of MIR160, MIR165/166, MIR167, MIR393, and MIR396 significantly affected the auxin accumulation and sensitivity to auxin in cultured explants of Arabidopsis [56,82,83,85].

The auxin-related miRNAs frequently target the fundamental components of the auxin signaling pathway, including the $A R F s$, which are involved in SE induction $[27,93]$. Accordingly, insights into embryogenic cultures of Arabidopsis and other plants indicated that miR160 could directly regulate the expression of ARF10, ARF16, and ARF17; miR167 seems to the control expression of ARF6 and ARF8, while miR390 possibly downregulates the ARF2, ARF3, ARF4 transcripts $[55,63,64,68,81,85,86]$.

One possible outcome of the miRNA-mediated gene regulation in SE is the establishment of explant polarity, which is believed to affect the effectiveness of SE induction [94,95]. The miR165/166-mediated control of auxin biosynthesis during SE could account for the enhanced embryogenic response of the adaxial vs. abaxial sides of the immature zygotic embryo (IZE) cotyledon explants of Arabidopsis [22]. In this scenario, the miR165/166-mediated restriction of the PHABULOSA/PHAVOLUTA (PHB/PHV) transcripts to the adaxial cotyledon side results in a side-specific auxin accumulation due to the PHB/PHV-mediated stimulation of the LEAFY COTYLEDON2 (LEC2)-controlled pathway of auxin biosynthesis [85]. Support for the role of miR166-mediated regulation in the establishment of the embryogenic competency in the explant was provided in a recent analysis of an embryogenic culture of Z. mays. A unique pattern of miR166 (and several other small RNAs, miR156, miR164, and tasiARFs) was found associated with a specific SE-responsive developmental stage of an explant, the IZE [96]. In leaf development, miR165/166 is under the control of ARF3 and ARF4, which are polarly distributed as a result of the miR390-dependent tasiARFs that move intracellularly from the adaxial to the abaxial side of a leaf $[97,98]$ (reviewed in [99]). Although whether or not miR390 controls ARF3/4 in 
SE-induced explants needs verification, the miR390-ARF3/4 module operates in the auxin-signaling pathway to regulate lateral root development [100] of genetic convergence into auxin-induced tissue dedifferentiation and callus formation in vitro [101].

In addition to targeting PHB/PHV, miR165/166 could also impact SE by repressing the WUSCHELRELATED HOMEOBOX5 (WOX5) TF, which has a reported role in the formation of the root apical meristem (RAM) in the somatic embryos of Arabidopsis [102,103]. Although miR165/166, together with miR160, is known to target WOX5 in order to regulate root development in zygotic embryos and seedlings [104,105], the contribution of the similar regulatory module to SE remains to be revealed.

Auxin-related miRNAs could contribute to SE induction by regulating the metabolic pathways connected with other hormones, including ethylene. Accordingly, GhmiR157a modulates the free auxin level in Gossypium hirsutum by controlling the ethylene content, which triggers the callus initiation and cellular dedifferentiation that are associated with the embryogenic transition of somatic cells [106].

The miRNA-mediated SE-regulatory network also involves miR164, which seems to control the CUP-SHAPED COTYLEDON1 (CUC1) and CUC2 genes in SE [55]. The CUC genes encode the TFs of the NAC family and control the establishment of the shoot apical meristem in the zygotic embryos of Arabidopsis [107]. It has also been found that TF TEOSINTE BRANCHED1, CYCLOIDEA and PCF (TCP3) can regulate the expression of miR164 during shoot meristem development [108].

The complex miRNA-mediated regulatory network of SE induction considers feedback loops between the miRNA and the targets. Accordingly, miR390-targeted ARF5/MONOPTEROS (MP) was recently found to bind auxin-responsive elements (AuxRE) in the promoter of the MIR390a gene to control the MIR390 expression in the root meristem [109]. Although both ARF5/MP and miR390 have been suggested to control SE induction in Arabidopsis, their regulatory interactions in this process require experimental validation $[55,93]$.

A regulatory feedback loop also operates within the miR393-TAAR (clade of TIR1/AFB auxin receptors) module with a central role in regulating the auxin responses during plant development via auxin-regulated degradation of Aux/IAA transcriptional repressors [57,110,111]. Similar to its function in planta, miR393 has been shown to modulate the expression of the TIR1 and AFB2 auxin receptors to control the sensitivity of explants to auxin treatment and homeostasis of auxin signaling during the embryogenic transition in Arabidopsis [56]. In addition to Arabidopsis, the expression of miR393 and its TIR1 and AFB targets has also been found in the SE-transcriptomes of other species, including Citrus sinensis [59], Dimocarpus longan [62], G. hirsutum [65], Z. mays [67], and Triticum aestivum [69], which suggests that there is a common miR393 function in auxin perception during SE induction.

The complex interactions of different miRNA-controlled modules could be expected in the auxin-induced SE. The miR165/166 together with miR160 have been postulated to contribute to the LEC2-controlled pathway of SE induction by targeting PHB/PHV and ARF10/ARF16, respectively [85]. A similar regulatory interaction between miR160 and miR165/166 was also recently found to control the auxin-mediated leaf development and drought tolerance in Arabidopsis [112]. The miRNA controlled ARFs of overlapping expression patterns could interact genetically to fine-tune the auxin responses. As an example, the miR160-repressed ARF17 interacts with the miR167-controlled ARF6 and ARF8 in the complex network controlling the adventitious root initiation [113]. Although the contribution of miR167-ARF8 to SE induction needs experimental verification, the role of this module in adjusting the cellular free auxin level in an O. sativa cell culture was reported [114].

Recently, the GROWTH-REGULATING FACTORs (GRF1, GRF4, GRF7, GRF8, and GRF9) and PLETHORA (PLT1 and PLT2) TFs have been postulated to be among targets of miR396 in an Arabidopsis embryogenic culture. The complex regulatory interactions within the miR396-GRF-PLT module that involve the negative and positive regulation of GRFs and PLT by miR396, respectively, could be assumed to control the embryogenic transition of the somatic plant cells [83]. Similarly, a miR396 function has been associated with regulating the developmental switch in the root stem cells in planta [115].

Little is known about the regulators of the SE-associated auxin-related miRNAs and among the candidates is FUSCA3 (FUS3), which is structurally and functionally related to LEC2, and was 
suggested to control the MIR156, MIR160, MIR166, and MIR396 genes in an embryogenic culture of Arabidopsis [116]. In addition, another key regulator of the embryogenic transition, the AGAMOUS LIKE15 (AGL15) TF, which interacts with LEC2 and FUS3 in the auxin-mediated pathway of SE induction (reviewed in [117]) has been postulated to control auxin signaling in both Arabidopsis and soybean via the direct stimulation of a miR167a-encoding gene [118].

It is noteworthy that in addition to controlling the SE-induction pathway, auxin-related miRNAs also appear to have a crucial impact on the embryogenic competency of an explant. A recent analysis of SE in maize showed that the specific developmental stage of an IZE explant recommended for efficient SE induction displayed a unique pattern of several auxin-related miRNAs, including miR156, miR164, miR166, and miR393 [97]. Similarly, in Arabidopsis, an efficient SE response is associated with a strictly defined developmental stage of an IZE explant, and this significantly limits the establishment of efficient in vitro regeneration systems for biotechnology [3]. Thus, defining the miRNA-status of the SE-responsive explant stage could contribute to identifying new factors that determine the embryogenic capacity of tissue and, as a result, improve the plant regeneration protocols for in vitro-recalcitrant genotypes.

\section{Epigenetic Modifications and Auxin Responses Interact Closely to Control the Embryogenic Transition}

\subsection{DNA Methylation}

In a pioneering work on DNA methylation in SE induction, a treatment with auxins but not cytokinins was found to increase the level of global DNA methylation in embryogenic cell cultures of Daucus carota [119]. The impact of 2,4-D on DNA methylation has also been confirmed in embryogenic cultures of Picea omorika [120], Malus xiaojinensis [121], and Glycine max [122]. The changes in global 5mC content in the auxin-induced embryogenic cultures of different plants have been associated with a differential gene expression [123], and an extensive modulation of the genes encoding both the methylases and demethylases of DNA has been attributed to the auxin-induced SE-transcriptomes of different plants, i.e., Populus trichocarpa, Arabidopsis, G. hirsutum, and G. max [122,124-126]. In Arabidopsis, DOMAINS REARRANGED METHYLTRANSFERASE1-2 (DRM1-2) are required for de novo methylation via RNA-directed DNA methylation (RdDM) pathway, while METHYLTRANSFERASE1 (MET1) and CHROMOMETHYLASE1-3 (CMT1-3) maintain the methylation pattern during DNA replication. Similar to the early stages of zygotic embryo formation [127], MET1 and CMT3 had a significantly higher expression level than DRM1 and DRM2 during SE in Arabidopsis [24]. Several reports have implied that auxin (2,4-D) treatment could regulate genes encoding (de)methylases differently, and consistently, an auxin medium increased the expression of the DRMs and CMT3 methylases and downregulated the expression of the (REPRESSOR OF SILENCING1) ROS1, DEMETER (DME), and DEMETER-LIKE PROTEIN2 (DML2) demethylases in embryogenic cultures of D. carota and Arabidopsis $[24,128,129]$. The presence of the auxin responsive AuxRE motif, in the CMT3 promoter, suggests a direct impact of auxin on gene transcription. In contrast, auxin seems to indirectly control the AuxRE-less promotor of the MET1 gene, and the underlying mechanism remains to be revealed.

Evidence for a link between DNA methylation and auxin signaling provides a significantly modified embryogenic response of Arabidopsis mutants impaired in methylases including met1 and $d r m$ [24]. A mutation in the MET1 gene, which significantly decreased the global level of DNA methylation [130], promoted faster in vitro shoot regeneration, due to early activation of auxin-induced WUSCHEL (WUS) [131]. In addition, the met1 mutation caused an abnormal auxin gradient in embryos and deregulation of the PIN-FORMED1 (PIN1) auxin efflux carrier engaged in polar auxin transport in plant development, including SE $[132,133]$. The role of DNA methylation in the regulation of the PIN-like proteins during somatic embryo development in Araucaria angustifolia has been suggested [134]. The expression of the DNA methylase genes in SE cultures, together with the significantly modified embryogenic response of the DNA methylase mutants, implies that both the maintenance and de novo pathways of DNA methylation are engaged in regulating SE induction. However, the complexity of the interactions controlling the balance between DNA replication de novo and the maintenance of 
DNA methylation and DNA demethylation [135] results in a lack of a direct relationship between the activity of the DNA (de)methylases and the global 5mC status of a genome $[136,137]$.

In the majority of reports, an inverse relationship has been observed between the embryogenic competence of explants/culture and the DNA methylation level. Accordingly, the hypomethylation of DNA seems to be associated with the early stages of embryogenic induction, and the embryogenic cultures have a lower level of $5 \mathrm{mC}$ than the non-embryogenic cultures (reviewed in [25]). However, the hypomethylation of DNA is not specific to the embryogenic induction and seems to be related to a general process of tissue dedifferentiation because both the embryogenic culture and non-embryogenic calli of Arabidopsis had a decreased $5 \mathrm{mC}$ content $[24,138]$. Conversely, the increased global level of DNA methylation could be associated with SE induction, as was reported in Eleuterococcus senticosus [139]. Because of the variety of factors, including the stress conditions, organ/tissue type and genotype impacting the methylation status of a genome [40], diversity in the SE-associated 5mC patterns could be expected between different embryogenic cultures.

The contrasting effects of a demethylation agent, 5-azacitidine (5-AzaC), treatment on the embryogenic response of plant tissue offer further evidence that a complex set of exo- and endogenous culture factors rather than the induction of embryonic development per se appear to shape the global DNA methylation level in in vitro cultured tissue. Accordingly, 5-AzaC treatment has been recommended for improving the embryogenic capacity of cultures derived from poorly responding plant explants and the genotypes of in vitro recalcitrant plant species [25] including the recovery of the SE potential in aged cultures of Theobroma cacao [140]. However, the 5-AzaC treated explants of Arabidopsis showed a significantly reduced SE capacity [24]. The factors that could modify the effect of 5-AzaC on in vitro cultured tissue involve hormonal treatment, and 2,4-D was reported to modulate the effect of 5-AzaC on the embryogenic response in Acca sellowiana in a concentration-dependent manner [141].

In contrast to the global level of $5 \mathrm{mC}$, which seems to be unspecific to embryogenic vs. non-embryogenic tissue [24], an analysis of DNA methylation in response to SE induction signal at the gene level could be more conclusive for revealing the interactions between the DNA methylation, auxin, and gene expression that promote SE. However, studies on the methylation of the specific genes associated with in vitro-induced plant morphogenesis, including SE, are rather limited. A decreased $5 \mathrm{mC}$ level has been found in the promotors of LEAFY COTYLEDON1 (LEC1) and WUS, respectively, in an embryogenic culture of $D$. carota [142] and during shoot organogenesis in Arabidopsis [131,143]. Similarly, a decreased methylation level has been reported in the SOMATIC EMBRYOGENESIS RECEPTOR-LIKE KINASE (SERK), LEC2, and WUS genes in the embryogenic calli of Boesenbergia rotunda [144]. Hypomethylation at the $\mathrm{CHH}$ sites in a promoter has been associated with the activation of some hormone related and WOX genes in G. hirsutum SE [126].

To summarize, the hypomethylation of the regulatory genes, including TFs, seems to be a typical response of de-differentiated somatic cells; however, more genes need to be analyzed to verify this assumption. Insight into the methylation of the specific sequences within genes is of particular interest given that DNA methylation is a site specifically regulated [52] and the methylation of the promoter and coding sequences seems to have a significantly different function $[40,145]$. Consistently, the decreased vs. increased number of genes with methylated P and GB sequences, respectively, have been found during an in vitro dedifferentiation and regeneration of $P$. trichocarpa [124].

In addition to auxin (2,4-D) treatment, the in vitro imposed abiotic stress could modulate plant somatic cell methylome given that differentiated genome methylation has been postulated as providing the adaptive mechanism to different stresses in plants [40,146]. This finding, together with dual, stress-, and auxin-like responses induced by 2,4-D make identifying the gene-specific DNA methylation patterns that promote auxin-induced SE challenging. 


\subsection{Histone Methylation}

Several reports have indicated the interplay between DNA and histone methylation in the chromatin remodeling to be associated with the in vitro-induced developmental processes, including $\mathrm{SE}$ in G. hirsutum [126]. A decrease in the $5 \mathrm{mC}$ level and histone methylation at the H3K9me2 and H3K9me3 markers has been attributed to the positive regulation of gene expression during plant cell dedifferentiation $[147,148]$. Similarly, a decrease in the DNA methylation level has been associated with a decrease of H3K9me2 and H3K27me3 during SE in Coffea canephora [149].

The involvement of PRC2-mediated histone methylation in the repression of the embryo maturation programs during the vegetative development in Arabidopsis has been indicated [18]. The cell fate can be reset, and SE could be induced in PRC2-depleted tissues treated with hormone [18]. The role of PRC2 in the reprogramming of somatic cells has also been suggested for the callus and somatic embryo production that is associated with the loss-of-function mutations in the genes encoding the proteins of the PRC2 complex, CURLY LEAF (CLF), SWINGER (SWN), VERNALIZATION2 (VRN2), and EMBRYONIC FLOWER2 (EMF2) [19]. Consistent with a pluripotency-related function, PRC2 has been suggested to target the TFs, including LEC1, LEC2, FUS3, AGL15, PLT, and WOXs, which have regulatory roles in somatic cell differentiation and SE induction in different plants including Arabidopsis, C. canephora, and Medicago truncatula [149-152]. Within the PRC2-repressed targets, the genes involved in biosynthesis, transport, perception, and signal transduction of auxin have been observed [17]. Accordingly, PRC2 has been found to directly silence the TRYPTOPHAN AMINOTRANSFERASE RELATED1 (TAR1) and YUCCA10 (YUC10) genes involved in the indole-3-acetaldoxime-mediated auxin biosynthesis pathway with a role in SE induction in Arabidopsis [153,154]. The role of PRC2 in controlling auxin responses in vitro also implies a significantly reduced level of H3K27me 3 in the chromatin-associated with the auxin-related genes, INDOLE-3-ACETIC ACID INDUCIBLE2 (IAA2), GH3.2, NITRILASE (NIT2), YUC4, IAA CARBOXYLMETHYLTRANSFERASE1 (IAMT1), and PIN1 during callus production [155]. The PRC2-mediated repression of the PIN1 auxin efflux carrier has been indicated to downregulate the auxin maxima in the lateral roots of Arabidopsis [156]. Because of the similarity of root development to the callus and plant regeneration pathway [101], including the role of YUC4 in both SE induction and lateral root development $[153,157]$, the PRC2 regulation of auxin transport during the embryogenic transition of somatic cells could be assumed.

The PRC1 complex in Arabidopsis consists of five proteins, AtRINGa/b and AtBMI1a-c, and the Atbmi1a Atbmi1b and Atring1a Atring1b double mutant seedlings have shown a spontaneous callus and somatic embryo formation $[14,15]$. Consistently, PRC1 was found to negatively control the TFs of a regulatory role in embryogenic development, including ABSCISIC ACID INSENSITIVE3 (ABI3), AGL15, BABY BOOM (BBM), FUS3, LEC1, LEC2, WOXs and the auxin transporters of the PIN family [15].

In line with the negative impact of PRC1 on SE, a decreased versus an increased expression of PRC1 genes (RING1, BMI1, LIKE HETEROCHROMATIN PROTEIN1 LHP1, EMBRYONIC FLOWER1 EMF1, and VERNALIZATION1 VRN1) has been found in the embryogenic vs. non-embryogenic genotypes of M. truncatula [16], respectively. In control of the SE-genes, the PRC1 complex interacts with the VP1/ABI3-LIKE1-3 (VAL1-3) proteins, and a high embryogenic potential of the val1 val2 mutant is accompanied by the activation of the embryonic genes LEC1, LEC2, FUS3, and ABI3 [158,159].

Unlike PRC1 and PRC2, the TrxG complexes are frequently associated with actively transcribed genes [160]. Interestingly, depending on the plant's developmental stage that is controlled, the proteins of the PRC and TrxG complexes can interact in an antagonistic vs. cooperative manner. For example, to prevent any precocious seed gene expression after germination, the ARABIDOPSIS HOMOLOG OF TRITHORAX1 (ATX1), ULTRAPETALA1 (ULT1) of the TrxG, and EMF1 of the PRC1/2 work together to maintain chromatin integrity [21]. The TrxG proteins control gene expression in plant development via multiple mechanisms that include modifying the chromatin structure via the deposition of the H3K4me2/3 marker [161]. The TrxG factors, the ATX1 of H3K4me3 methyltransferase activity, and ULT1 interact physically to reduce the H3K27me3 marker in the targeted genes, including the SE-regulators, 
LEC1, LEC2, FUS3, and ABI3 [20]. The direct binding of both ATX1 and ULT1 to the seed gene loci, $A B I 3$ and $L E C 2$, was observed [21].

The essential regulatory function of TrxG/PRC complexes in the auxin-mediated processes implied a vast number of the auxin-related genes that showed a misregulation of expression in the mutants impaired in the genes encoding the TrxG and PRC proteins [21]. BRAHMA (BRM) of the TrxG complex has been found to directly activate the auxin efflux carriers (PINs) in part by antagonizing the H3K27me3-associated chromatin repression that is mediated by the PcG proteins [162]. The proteins of TrxG also cooperate with the components of the auxin signaling pathway, and in response to auxin, ARF5 recruits the chromatin remodeling complexes (BRM and SPLAYED) to the target loci in order to overcome the repressed chromatin state [163].

The histone methylation-mediated control of gene expression is also orchestrated by other proteins that act antagonistically to PcG. Among them, the members of the JUMONJI C (JmjC)-domaincontaining-protein family have been identified. These proteins regulate various genes, including the PIN auxin carriers and auxin biosynthesis YUC3 gene via the direct histone demethylation $[164,165]$. Further studies are needed to determine whether the (JmjC)-domain-containing-proteins also control the auxin-related SE response.

\subsection{Histone Acetylation}

A model of the histone acetylation contribution to auxin signaling considers interactions between the auxin-responsive elements (AuxRE) and the HAT acetylases [166]. Consistently, AuxREs have been identified in the promoters of the majority of the TF genes of upregulated expression during SE induced in Arabidopsis with the HDAC-inhibitor, trichostatin A (TSA) [22]. Evidence of the contribution of the (de)acetylation of histones to the in vitro-induced embryogenic transition also provides the differential expression of several members of the HDAC and HAT gene families in the SE transcriptomes of plants [125,167-169]. Two of the deacetylases, HDAC6 and HDAC19, seem to be of particular importance in SE induction as the $h d a c 6 / h d a c 19$ mutant plants showed somatic embryo development on their leaves [23]. The HDAC6 and HDAC19 control the genes expression in zygotic embryos, and the HDAC19-mediated repression of LEC1 and LEC2 via the deacetylation of histone $\mathrm{H} 3$ was reported [170-172].

Experimental evidence about the histone acetylation-mediated control of in vitro-induced plant morphogenesis, including SE are still limited; however, several reports have indirectly implied such a control. An increased level of $\mathrm{H} 3$ and $\mathrm{H} 4$ acetylation associated with the expression of the histone acetyltransferase genes has been demonstrated during the microspore embryogenesis of Brassica napus [167] and an increased level of a specific histone acetylation marker (H3K9 and 14) accompanied the chromatin decondensation and transcriptional activation of the genes during the dedifferentiation of Nicotiana tabacum protoplasts [173]. Experiments with TSA also suggest that histone acetylation plays a role in SE control [174], and the TSA-mediated inhibition of HDACs results in histone hyperacetylation and conformational changes of the chromatin-associated with enhanced gene expression [175]. Consistently, an increase in the H3K9/K14Ac and H4K5Ac epigenetic markers was reported in the TSA-treated seedlings of Arabidopsis [176,177]. In support of a role of histone acetylation in controlling SE induction, TSA treatment promoted the development of embryogenic structures on the seedlings and in vitro-cultured explants of Arabidopsis and conifers $[22,23,178,179]$ and the beneficial effects of TSA on microspore cultures of T. aestivum [180] and B. napus [181] were reported. Nonetheless, details of the TSA-promoted regulatory interactions that provoke an embryogenic response in somatic plant cells has not yet been clarified. Some clues about the TSA-mediated SE induction mechanism indicated an auxin accumulation accompanied by the upregulation of the auxin-related SE-regulators, including $L E C 1, L E C 2, B B M$, and PHB in a TSA-induced embryogenic culture of Arabidopsis [22]. In addition to Arabidopsis, the TSA-induced upregulation of $L E C 1$ and $L E C 2$ has also been reported in microspore culture of B. napus [181], and the transcripts of LEC1-type HAP3 were accumulated in the TSA-treated IZEs of Picea abies [178]. Consistent with the TSA-upregulated expression of 
$L E C 1$ and $L E C 2$, the histone deacetylase complex was implicated in the repression of the LECS and other genes of the LAFL (LEC1, ABI3, FUS3, LEC2) network, which controls seed development [182]. Interestingly, insight into the TF genes expressed in plant embryogenic cultures suggests that histone acetylation could preferentially activate the expression of the auxin-responsive $T F$ genes $[22,23,178,181]$. In addition to TFs, the genes that were upregulated in the TSA-induced SE included the YUC (YUC1 and YUC10) genes of the auxin biosynthesis pathway [22] and the genes associated with the metabolism (GH3), transport (PIN1, PIN3, and PIN7) and signaling (AFB3) of auxin [181]. Similar to plants, TSA was found to derepress the transcription of the $T F$ genes controlling the reprogramming of mammal somatic cells into embryonic stem cells [183]. The gene-specific effects of TSA were postulated, and in support, the non-stochastic impact of TSA treatment on the transcriptomes of diverse organisms, including humans, other mammals, and Arabidopsis, was reported [176,183,184].

The detailed mechanisms by which the TSA-modulated histone acetylation status of chromatin affects the SE-involved genes remains elusive. In a possible scenario, the SE-induction signal (provided by TSA or 2,4-D treatment) promotes histone acetylation and activates the genes encoding the pioneer TF of a crucial function in the embryogenic transition, including LEC1 [185]. LEC1 is assumed to act as a pioneer TF that promotes the post-translational modifications of the core histones involved in regulating gene expression [186]. It is noteworthy that among the direct targets of LEC1, the TFs encoding the LAFL-group regulators of the SE-involved auxin biosynthesis pathway were identified [117,172].

The current model of auxin-regulated gene expression implies a relationship between the auxin- and TSA-responsiveness of genes (reviewed in [9]). Consistent with this model, some genetic convergence of the TSA- and 2,4-D-induced embryogenic development was revealed in Arabidopsis [22]. Similar to in planta development, auxins could promote SE-regulatory genes via the histone acetylation-mediated derepression of gene transcription. Moreover, the capacity of TSA for gene derepression seems to be stronger than that of 2,4-D, as TSA is exclusively able to activate the SE-regulatory genes in the post-germinated tissue of Arabidopsis [23]. Thus, although TSA seems to target the auxin-responsive genes preferentially, the effects of TSA vs. 2,4-D on the gene expression level could differ to some extent. In support of this, the downregulation vs. the upregulation of ARF10 and ARF17 during TSA- vs. 2,4-D-induced SE, respectively, was reported in Arabidopsis [22,93]. The targets of histone acetylation also involve the MIRNA genes, including those encoding auxin-related miRNA [187-190]. TSA treatment affected the accumulation of miRNAs, and GCN5-dependent H3K14 acetylation was required for the transcriptional regulation of the auxin-related miR164, miR165, and miR167, which have a regulatory function in SE induction in Arabidopsis [55,187,188].

It is also possible that the TSA-induced SE mechanism could comprise other TSA-affected epigenetic processes, including the methylation of DNA and histones [191,192] and other TSA-targeted modifications which are unrelated to gene transcription. Hence, understanding the intricate mechanisms that control the derepression of the embryogenic potential in somatic plant cells requires deciphering the complex interplay between histone and non-histone acetylation and the other epigenetic processes that regulate gene expression.

\section{Concluding Remarks and Perspectives}

The extensive studies on embryogenic cultures of plants, primarily on the model plant Arabidopsis, have revealed the complex interactions between the regulatory genes in which the auxin-related epigenetic processes have been found to play a central role (Figure 2). Although the SE-regulatory network has some similarities to the genetic and epigenetic control of zygotic embryogenesis, recent RNAseq data of an embryogenic culture of Arabidopsis unexpectedly revealed that the SE transcriptome differs from the early transcriptome of a zygotic embryo and resembles the gene expression pattern of germinating seeds [193]. These results shed new light on the molecular events that control SE induction and indicate that identifying the core, canonical components of the common molecular regulatory pathway governing embryonic development in zygotic and somatic plant cells could be 
extremely challenging. Moreover, due to the variety of endo- and exogenous factors that orchestrate the cell transcriptomes, a high degree of diversity could be expected between the SE transcriptomes. Thus, searching for the epigenetic events that determine the SE-response in various plants and explant types could be of particular interest in further investigations of the regulatory determinants of the embryogenic response. Methylation-related processes seem to be of particular interest as the genes involved in the methylation of DNA and histones have recently been found to be predominantly active during the epigenetic reprogramming in early zygotic embryogenesis [194].

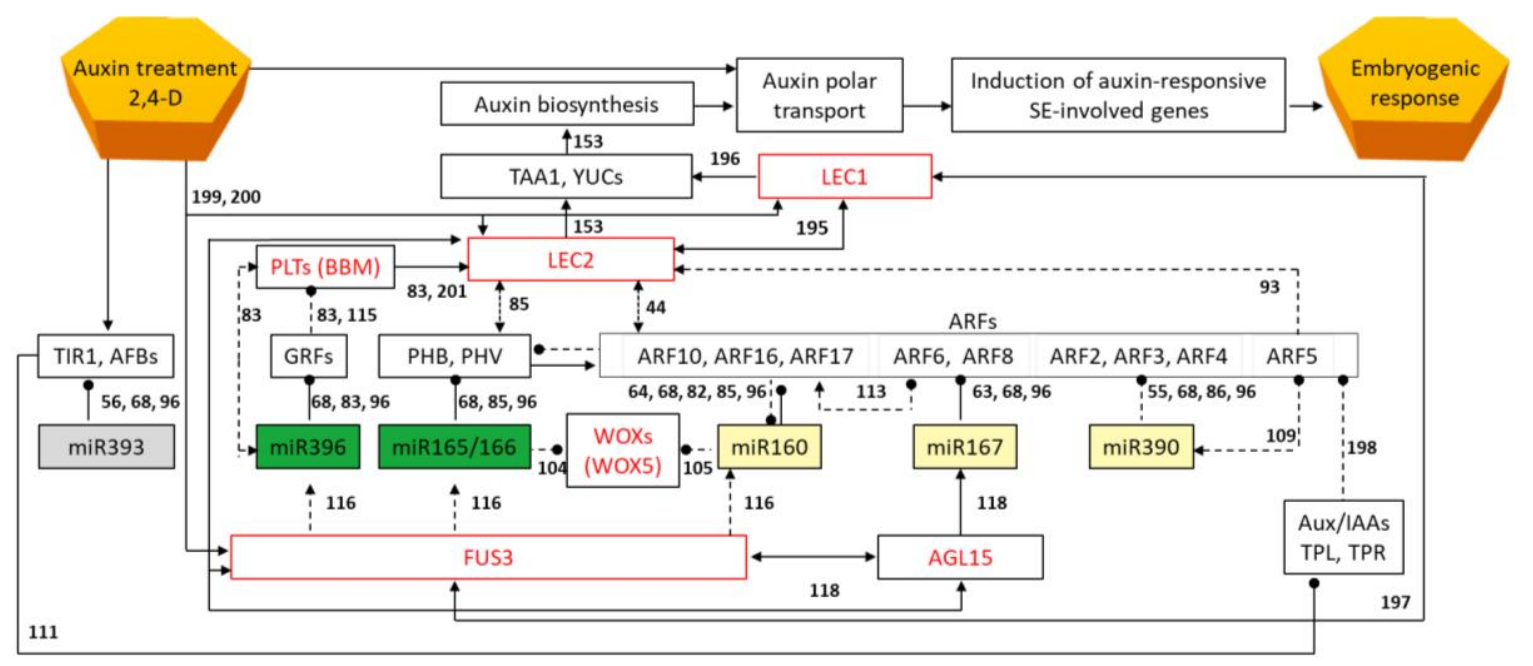

Figure 2. The regulatory network controlling SE induction in which the auxin-related epigenetic processes play a central role. A number of auxin-related miRNAs orchestrate the explant cell transcriptome towards embryogenic transition through regulation of auxin perception (miR393), biosynthesis (miR396 and miR165/166), and signaling (miR160, mi167, and miR390). The SE-involved miRNAs control embryogenic induction by targeting the $T F$ genes with a key regulatory function in embryonic development including the LEC1, LEC2, and FUS3 of the LEC group; BBM (PLTS); AGL15 and WOXs (WOX5) genes; and a number of $A R F \mathrm{~s}$ involved in the auxin-signaling pathway. The miRNAs controlling auxin perception, biosynthesis, and signaling are indicated by the grey, green and yellow boxes, respectively. The key TFs are marked in red including the genes of the LEC group, which are distinguished by red-framed boxes. Arrows and circle-shaped ends show the activation or repression of gene expression, respectively. Solid vs. dashed lines refer to the experimentally validated and suggested regulatory interactions that operate during SE, respectively [195-201]. (2,4-D) 2,4-dichlorophenoxyacetic acid; (AFBs) AUXIN F-BOX PROTEINs; (AGL15) AGAMOUS-LIKE15; (ARF) AUXIN RESPONSE FACTOR; (Aux/IAA) AUXIN/INDOLE-3ACETIC ACID; (BBM) BABY BOOM; (FUS3) FUSCA3; (GRFs) GROWTH-REGULATING FACTORs; (LEC1,2) LEAFY COTYLEDON1,2; (miR) microRNA; (PHB) PHABULOSA; (PHV) PHAVOLUTA; (PLT) PLETHORA; (TAA1) TRYPTOPHAN AMINOTRANSFERASE OF ARABIDOPSIS1; (TIR1) TRANSPORT INHIBITOR1; (TPL) TOPLESS; (TPR) TOPLESS RELATED; (WOX) WUSCHEL-RELATED HOMEOBOX; (WUS) WUSCHEL; (YUC) YUCCA.

Author Contributions: All of the authors listed have made a substantial, direct, and intellectual contribution to the work and approved it for publication. All authors have read and agreed to the published version of the manuscript.

Funding: This work was supported by a research grant from the National Science Centre in Poland (OPUS13 2017/25/B/NZ1/01615).

Conflicts of Interest: The authors declare no conflict of interest. 


\section{Abbreviations}

$\begin{array}{ll}\text { 2,4-D } & \text { 2,4-dichlorophenoxyacetic acid } \\ \text { 5-AzaC } & \text { 5-azacitidine } \\ \text { 5mC } & \text { 5-methylcytosine } \\ \text { ABI3 } & \text { ABSCISIC ACID INSENSITIVE3 } \\ \text { AFB } & \text { AUXIN F-BOX PROTEIN } \\ \text { AGL15 } & \text { AGAMOUS-LIKE15 } \\ \text { ARF } & \text { AUXIN RESPONSE FACTOR } \\ \text { AuxRE } & \text { AUXIN RESPONSIVE ELEMENT } \\ \text { CMT } & \text { CHROMOMETHYLASE } \\ \text { FUS3 } & \text { FUSCA3 } \\ \text { GB } & \text { gene body } \\ \text { HAT } & \text { HISTONE ACETYLTRANSFERASE } \\ \text { HDAC } & \text { HISTONE DEACETYLASE } \\ \text { IZE } & \text { IMMATURE ZYGOTIC EMBRYO } \\ \text { LEC } & \text { LEAFY COTYLEDON } \\ \text { MET1 } & \text { METHYLTRANSFERASE1 } \\ \text { miRNA } & \text { microRNA } \\ \text { P } & \text { promotor } \\ \text { PcG } & \text { Polycomb-group } \\ \text { PHB } & \text { PHABULOSA } \\ \text { PHV } & \text { PHAVOLUTA } \\ \text { PIN } & \text { PIN-FORMED } \\ \text { PLT } & \text { PLETHORA } \\ \text { PRC } & \text { POLYCOMB REPRESSIVE COMPLEX } \\ \text { SE } & \text { somatic embryogenesis } \\ \text { TF } & \text { transcription factor } \\ \text { TIR1 } & \text { TRANSPORT INHIBITOR1 } \\ \text { TrXG } & \text { Trithorax-group } \\ \text { TSA } & \text { trichostatin A } \\ \text { WOX } & \text { WUSCHEL RELATED HOMEOBOX } \\ \text { WUS } & \text { WUSCHEL } \\ \text { YUC } & \text { YUCCA } \\ & \end{array}$

\section{References}

1. Ochoa-Alejo, N. The uses of somatic embryogenesis for genetic transformation. In Somatic Embryogenesis: Fundamental Aspects and Applications, 1st ed.; Loyola-Vargas, V., Ochoa-Alejo, N., Eds.; Springer International Publishing: Cham, Switzerland, 2016; pp. 415-434.

2. Fehér, A. Callus, dedifferentiation, totipotency, somatic embryogenesis: What these terms mean in the era of molecular plant biology? Front. Plant Sci. 2019, 10, 1-11. [CrossRef]

3. Wójcikowska, B.; Gaj, M.D. Somatic embryogenesis in Arabidopsis. In Somatic Embryogenesis: Fundamental Aspects and Applications, 1st ed.; Loyola-Vargas, V., Ochoa-Alejo, N., Eds.; Springer International Publishing: Cham, Switzerland, 2016; pp. 185-199.

4. Gaj, M.D. Direct somatic embryogenesis as a rapid and efficient system for in vitro regeneration of Arabidopsis thaliana. Plant Cell Tissue Organ Cult. 2001, 64, 39-46. [CrossRef]

5. Mujib, A. Somatic Embryogenesis in Ornamentals and Its Applications; Springer: New Delhi, India, 2016; pp. 67-86.

6. Paque, S.; Weijers, D. Q \& A: Auxin: The plant molecule that influences almost anything. BMC Biol. 2016, 14, 67.

7. Winnicki, K. The winner takes it all: Auxin-The main player during plant embryogenesis. Cells 2020, 9, 606. [CrossRef]

8. Casanova-Sáez, R.; Voß, U. Auxin metabolism controls developmental decisions in land plants. Trends Plant Sci. 2019, 24, 741-754. [CrossRef] 
9. Weijers, D.; Wagner, D. Transcriptional responses to the auxin hormone. Annu. Rev. Plant Biol. 2016, 67, 539-574. [CrossRef]

10. Yamamuro, C.; Zhu, J.K.; Yang, Z. Epigenetic modifications and plant hormone action. Mol. Plant 2016, 9, 57-70. [CrossRef]

11. Zhu, Y. The epigenetic involvement in plant hormone signaling. Chin. Sci. Bull. 2010, 55, 2198-2203. [CrossRef]

12. Maury, S.; Sow, M.D.; Le Gac, A.L.; Genitoni, J.; Lafon-Placette, C.; Mozgova, I. Phytohormone and chromatin crosstalk: The missing link for developmental plasticity? Front. Plant Sci. 2019, 10, 395. [CrossRef]

13. Nadarajah, K.; Kumar, I.S. Drought response in rice: The miRNA story. Int. J. Mol. Sci. 2019, $20,3766$. [CrossRef]

14. Bratzel, F.; López-Torrejón, G.; Koch, M.; Del Pozo, J.C.; Calonje, M. Keeping cell identity in Arabidopsis requires PRC1 RING-finger homologs that catalyze H2A monoubiquitination. Curr. Biol. 2010, 20, 1853-1859. [CrossRef] [PubMed]

15. Chen, D.; Molitor, A.; Liu, C.; Shen, W.H. The Arabidopsis PRC1-like ring-finger proteins are necessary for repression of embryonic traits during vegetative growth. Cell Res. 2010, 20, 1332-1344. [CrossRef] [PubMed]

16. Orłowska, A.; Kępczyńska, E. Identification of polycomb repressive Complex1, Trithorax group genes and their simultaneous expression with WUSCHEL, WUSCHEL-related Homeobox5 and SHOOT MERISTEMLESS during the induction phase of somatic embryogenesis in Medicago truncatula Gaertn. Plant Cell Tissue Organ Cult. 2018, 134, 345-356. [CrossRef]

17. Lafos, M.; Kroll, P.; Hohenstatt, M.L.; Thorpe, F.L.; Clarenz, O.; Schubert, D. Dynamic regulation of H3K27 trimethylation during Arabidopsis differentiation. PLoS Genet. 2011, 7, e1002040. [CrossRef] [PubMed]

18. Mozgová, I.; Muñoz-Viana, R.; Hennig, L. PRC2 Represses hormone-induced somatic embryogenesis in vegetative tissue of Arabidopsis thaliana. PLoS Genet. 2017, 13, e1006562. [CrossRef] [PubMed]

19. Chanvivattana, Y.; Bishopp, A.; Schubert, D.; Stock, C.; Moon, Y.H.; Sung, Z.R.; Goodrich, J. Interaction of Polycomb-group proteins controlling flowering in Arabidopsis. Development 2004, 131, 5263-5276. [CrossRef]

20. de la Paz Sanchez, M.; Aceves-García, P.; Petrone, E.; Steckenborn, S.; Vega-León, R.; Álvarez-Buylla, E.R.; Garay-Arroyo, A.; García-Ponce, B. The impact of Polycomb group (PcG) and Trithorax group (TrxG) epigenetic factors in plant plasticity. New Phytol. 2015, 208, 684-694. [CrossRef]

21. Xu, F.; Kuo, T.; Rosli, Y.; Liu, M.S.; Wu, L.; Chen, L.F.O.; Fletcher, J.C.; Sung, Z.R.; Pu, L. Trithorax group proteins act together with a polycomb group protein to maintain chromatin integrity for epigenetic silencing during seed germination in Arabidopsis. Mol. Plant 2018, 11, 659-677. [CrossRef]

22. Wójcikowska, B.; Botor, M.; Morończyk, J.; Wójcik, A.M.; Nodzyński, T.; Karcz, J.; Gaj, M.D. Trichostatin a triggers an embryogenic transition in Arabidopsis explants via an auxin-related pathway. Front. Plant Sci. 2018, 9, 1-19. [CrossRef]

23. Tanaka, M.; Kikuchi, A.; Kamada, H. The Arabidopsis histone deacetylases HDA6 and HDA19 contribute to the repression of embryonic properties after germination. Plant Physiol. 2008, 146, 149-161. [CrossRef] [PubMed]

24. Grzybkowska, D.; Morończyk, J.; Wójcikowska, B.; Gaj, M.D. Azacitidine (5-AzaC)-treatment and mutations in DNA methylase genes affect embryogenic response and expression of the genes that are involved in somatic embryogenesis in Arabidopsis. Plant Growth Regul. 2018, 85, 243-256. [CrossRef]

25. Osorio-Montalvo, P.; Sáenz-Carbonell, L.; De-la-Peña, C. 5-Azacytidine: A promoter of epigenetic changes in the quest to improve plant somatic embryogenesis. Int. J. Mol. Sci. 2018, 19, 3182. [CrossRef] [PubMed]

26. Bartel, D.P. MicroRNAs: Target recognition and regulatory functions. Cell 2009, 136, 215-233. [CrossRef]

27. Rubio-Somoza, I.; Weigel, D. MicroRNA networks and developmental plasticity in plants. Trends Plant Sci. 2011, 16, 258-264. [CrossRef] [PubMed]

28. Rhoades, M.W.; Reinhart, B.J.; Lim, L.P.; Burge, C.B.; Bartel, B.; Bartel, D.P. Prediction of plant microRNA targets. Cell 2002, 110, 513-520. [CrossRef]

29. D'Ario, M.; Griffiths-Jones, S.; Kim, M. Small RNAs: Big impact on plant development. Trends Plant Sci. 2017, 22, 1056-1068. [CrossRef] [PubMed]

30. Song, X.; Li, Y.; Cao, X.; Qi, Y. MicroRNAs and their regulatory roles in plant-environment interactions. Annu. Rev. Plant Biol. 2019, 70, 489-525. [CrossRef]

31. Hobert, O. Common logic of transcription factor and microRNA action. Trends Biochem. Sci. 2004, 29, 462-468. [CrossRef] 
32. Jones-Rhoades, M.W.; Bartel, D.P.; Bartel, B. MicroRNAs and their regulatory roles in plants. Annu. Rev. Plant Biol. 2006, 57, 19-53. [CrossRef]

33. Feng, S.; Jacobsen, S.E.; Reik, W. Epigenetic reprogramming in plant and animal development. Science 2010, 330, 622-627. [CrossRef]

34. Lauria, M.; Rossi, V. Epigenetic control of gene regulation in plants. Biochim. Biophys. Acta Gene Regul. Mech. 2011, 1809, 369-378. [CrossRef] [PubMed]

35. Zilberman, D.; Gehring, M.; Tran, R.K.; Ballinger, T.; Henikoff, S. Genome-Wide analysis of Arabidopsis thaliana DNA methylation uncovers an interdependence between methylation and transcription. Nat. Genet. 2007, 39, 61-69. [CrossRef] [PubMed]

36. Stricker, S.H.; Köferle, A.; Beck, S. From profiles to function in epigenomics. Nat. Rev. Genet. 2017, 18, 51-66. [CrossRef]

37. Stricker, S.H.; Götz, M. DNA-Methylation: Master or slave of neural fate decisions? Front. Neurosci. 2018, 12, 5. [CrossRef] [PubMed]

38. Zilberman, D. An evolutionary case for functional gene body methylation in plants and animals. Genome Biol. 2017, 18, 17-19. [CrossRef]

39. Aceituno, F.F.; Moseyko, N.; Rhee, S.Y.; Gutiérrez, R.A. The rules of gene expression in plants: Organ identity and gene body methylation are key factors for regulation of gene expression in Arabidopsis thaliana. BMC Genom. 2008, 9, 1-14. [CrossRef]

40. Zhang, H.; Lang, Z.; Zhu, J.K. Dynamics and function of DNA methylation in plants. Nat. Rev. Mol. Cell Biol. 2018, 19, 489-506. [CrossRef]

41. Trejo-Arellano, M.S.; Mahrez, W.; Nakamura, M.; Moreno-Romero, J.; Nanni, P.; Köhler, C.; Hennig, L. H3K23me1 is an evolutionarily conserved histone modification associated with CG DNA methylation in Arabidopsis. Plant J. 2017, 90, 293-303. [CrossRef]

42. Xiao, J.; Lee, U.S.; Wagner, D. Tug of war: Adding and removing histone lysine methylation in Arabidopsis. Curr. Biol. 2016, 34, 41-53. [CrossRef]

43. Duarte-Aké, F.; Nic-Can, G.; De-la-Peña, C. Somatic embryogenesis: Polycomb complexes control cell-to-embryo transition. In Epigenetics in Plants of Agronomic Importance: Fundamentals and Applications; Alvarez-Venegas, R., De-la-Peña, C., Casas-Mollano, J., Eds.; Springer: Cham, Switzerland, 2019; pp. 339-354.

44. Mozgova, I.; Köhler, C.; Hennig, L. Keeping the gate closed: Functions of the polycomb repressive complex PRC2 in development. Plant J. 2015, 83, 121-132. [CrossRef]

45. Simon, J.A.; Kingston, R.E. Mechanisms of Polycomb gene silencing: Knowns and unknowns. Nat. Rev. Mol. Cell Biol. 2009, 10, 697-708. [CrossRef] [PubMed]

46. Lee, C.Y.; Grant, P.A. Role of histone acetylation and acetyltransferases in gene regulation. In Toxicoepigenetics; McCullough, S., Dolinoy, D., Eds.; Elsevier Academic Press: Cambridge, MA, USA, 2019; pp. 3-30.

47. Steunou, A.L.; Rossetto, D.; Côté, J. Regulating chromatin by histone acetylation. In Fundamentals of Chromatin; Workman, J.L., Abmayr, S.L., Eds.; Springer: New York, NY, USA, 2013; pp. 147-212.

48. Wang, Z.; Cao, H.; Chen, F.; Liu, Y. The roles of histone acetylation in seed performance and plant development. Plant Physiol. Biochem. 2014, 84, 125-133. [CrossRef] [PubMed]

49. Liu, X.; Yang, S.; Zhao, M.; Luo, M.; Yu, C.W.; Chen, C.Y.; Tai, R.; Wu, K. Transcriptional repression by histone deacetylases in plants. Mol. Plant 2014, 7, 764-772. [CrossRef] [PubMed]

50. Feng, W.; Michaels, S.D. Accessing the inaccessible: The organization, transcription, replication, and repair of heterochromatin in plants. Annu. Rev. Genet. 2015, 49, 439-459. [CrossRef] [PubMed]

51. Zhang, Y.; Reinberg, D. Transcription regulation by histone methylation: Interplay between different covalent modifications of the core histone tails. Genes Dev. 2001, 15, 2343-2360. [CrossRef]

52. Stroud, H.; Greenberg, M.V.C.; Feng, S.; Bernatavichute, Y.V.; Jacobsen, S.E. Comprehensive analysis of silencing mutants reveals complex regulation of the Arabidopsis methylome. Cell 2013, 152, 352-364. [CrossRef] [PubMed]

53. Wójcik, A.M.; Wójcikowska, B.; Gaj, M.D. Current perspectives on the auxin-mediated genetic network that controls the induction of somatic embryogenesis in plants. Int. J. Mol. Sci. 2020, 21, 1333. [CrossRef]

54. Gliwicka, M.; Nowak, K.; Balazadeh, S.; Mueller-Roeber, B.; Gaj, M.D. Extensive modulation of the transcription factor transcriptome during somatic embryogenesis in Arabidopsis thaliana. PLoS ONE 2013, 8, e69261. [CrossRef] 
55. Szyrajew, K.; Bielewicz, D.; Dolata, J.; Wójcik, A.M.; Nowak, K.; Szczygieł-Sommer, A.; SzweykowskaKulinska, Z.; Jarmolowski, A.; Gaj, M.D. MicroRNAs are intensively regulated during induction of somatic embryogenesis in Arabidopsis. Front. Plant Sci. 2017, 8, 1-16. [CrossRef]

56. Wójcik, A.M.; Gaj, M.D. miR393 contributes to the embryogenic transition induced in vitro in Arabidopsis via the modification of the tissue sensitivity to auxin treatment. Planta 2016, 244, 231-243. [CrossRef]

57. Chen, C.J.; Liu, Q.; Zhang, Y.C.; Qu, L.H.; Chen, Y.Q.; Gautheret, D. Genome-Wide discovery and analysis of microRNAs and other small RNAs from rice embryogenic callus. RNA Biol. 2011, 8, 538-547. [CrossRef] [PubMed]

58. Wu, X.M.; Liu, M.Y.; Ge, X.X.; Xu, Q.; Guo, W.W. Stage and tissue-specific modulation of ten conserved miRNAs and their targets during somatic embryogenesis of Valencia sweet orange. Planta 2011, 233, 495-505. [CrossRef] [PubMed]

59. Wu, X.M.; Kou, S.J.; Liu, Y.L.; Fang, Y.N.; Xu, Q.; Guo, W.W. Genomewide analysis of small RNAs in nonembryogenic and embryogenic tissues of citrus: microRNA-and siRNA-mediated transcript cleavage involved in somatic embryogenesis. Plant Biotechnol. J. 2015, 13, 383-394. [CrossRef] [PubMed]

60. Long, J.; Liu, C.; Feng, M.; Liu, Y.; Wu, X.; Guo, W. miR156-SPLs module regulates somatic embryogenesis induction in citrus callus. J. Exp. Bot. 2018, 69, 2979-2993. [CrossRef] [PubMed]

61. Li, T.; Chen, J.; Qiu, S.; Zhang, Y.; Wang, P.; Yang, L.; Lu, Y.; Shi, J. Deep sequencing and microarray hybridization identify conserved and species-specific microRNAs during somatic embryogenesis in hybrid yellow poplar. PLoS ONE 2012, 7, e43451. [CrossRef]

62. Lin, Y.; Lai, Z. Comparative analysis reveals dynamic changes in miRNAs and their targets and expression during somatic embryogenesis in longan (Dimocarpus longan Lour.). PLoS ONE 2013, 8, e60337. [CrossRef]

63. Lin, Y.; Lai, Z.; Lin, L.; Lai, R.; Tian, Q.; Ye, W.; Zhang, D.; Yang, M.; Chen, Y.; Zhang, Z. Endogenous target mimics, microRNA167, and its targets ARF6 and ARF8 during somatic embryo development in Dimocarpus longan Lour. Mol. Breed. 2015, 35, 1-15. [CrossRef]

64. Lin, Y.; Lai, Z.; Tian, Q.; Lin, L.; Lai, R.; Yang, M.; Zhang, D.; Chen, Y.; Zhang, Z.; Tian, Q.; et al. Endogenous target mimics down-regulate miR160 mediation of ARF10, -16, and -17 cleavage during somatic embryogenesis in Dimocarpus longan Lour. Front. Plant Sci. 2015, 6, 1-16. [CrossRef]

65. Yang, X.; Wang, L.; Yuan, D.; Lindsey, K.; Zhang, X. Small RNA and degradome sequencing reveal complex miRNA regulation during cotton somatic embryogenesis. J. Exp. Bot. 2013, 64, 1521-1536. [CrossRef]

66. Chávez-Hernández, E.C.; Alejandri-Ramírez, N.D.; Juárez-González, V.T.; Dinkova, T.D. Maize miRNA and target regulation in response to hormone depletion and light exposure during somatic embryogenesis. Front. Plant Sci. 2015, 6, 1-14. [CrossRef]

67. Alejandri-Ramírez, N.D.; Chávez-Hernández, E.C.; Contreras-Guerra, J.L.; Reyes, J.L.; Dinkova, T.D. Small RNA differential expression and regulation in Tuxpeño maize embryogenic callus induction and establishment. Plant Physiol. Biochem. 2018, 122, 78-89. [CrossRef] [PubMed]

68. López-Ruiz, B.A.; Juárez-González, V.T.; Sandoval-Zapotitla, E.; Dinkova, T.D. Development-related miRNA expression and target regulation during staggered in vitro plant regeneration of tuxpeño VS-535 maize cultivar. Int. J. Mol. Sci. 2019, 20, 2079. [CrossRef]

69. Chu, Z.; Chen, J.; Xu, H.; Dong, Z.; Chen, F.; Cui, D. Identification and comparative analysis of microRNA in wheat (Triticum aestivum L.) callus derived from mature and immature embryos during in vitro culture. Front. Plant Sci. 2016, 7, 1302. [CrossRef]

70. Liu, Y.; Han, S.; Ding, X.; Li, X.; Zhang, L.; Li, W.; Xu, H.; Li, Z.; Qi, L. Transcriptome analysis of mRNA and miRNA in somatic embryos of Larix leptolepis subjected to hydrogen treatment. Int. J. Mol. Sci. 2016, 17, 1951. [CrossRef] [PubMed]

71. Zhang, J.; Xue, B.; Gai, M.; Song, S.; Jia, N.; Sun, H. Small RNA and transcriptome sequencing reveal a potential miRNA-mediated interaction network that functions during somatic embryogenesis in Lilium pumilum DC. Fisch. Front. Plant Sci. 2017, 8, 1-18. [CrossRef] [PubMed]

72. Li, Q.; Deng, C.; Xia, Y.; Kong, L.; Zhang, H.; Zhang, S.; Wang, J. Identification of novel miRNAs and miRNA expression profiling in embryogenic tissues of Picea balfouriana treated by 6-benzylaminopurine. PLoS ONE 2017, 12, e0176112. [CrossRef]

73. Li, Q.; Deng, C.; Zhu, T.; Ling, J.; Zhang, H.; Kong, L.; Zhang, S.; Wang, J.; Chen, X. Dynamics of physiological and miRNA changes after long-term proliferation in somatic embryogenesis of Picea balfouriana. Trees Struct. Funct. 2019, 33, 469-480. [CrossRef] 
74. Sabana, A.A.; Antony, G.; Rahul, C.U.; Rajesh, M.K. In silico identification of microRNAs and their targets associated with coconut embryogenic calli. Agri Gene 2018, 7, 59-65. [CrossRef]

75. Rodrigues, A.S.; Chaves, I.; Costa, B.V.; Lin, Y.C.; Lopes, S.; Milhinhos, A.; Van de Peer, Y.; Miguel, C.M. Small RNA profiling in Pinus pinaster reveals the transcriptome of developing seeds and highlights differences between zygotic and somatic embryos. Sci. Rep. 2019, 9, 1-14. [CrossRef]

76. Siddiqui, Z.H.; Abbas, Z.K.; Ansari, M.W.; Khan, M.N. The role of miRNA in somatic embryogenesis. Genomics 2018, 111, 1026-1033. [CrossRef]

77. López-Ruiz, B.A.; Juárez-González, V.T.; Luján-Soto, E.; Dinkova, T.D. The role of small RNAs in plant somatic embryogenesis. In Epigenetics in Plants of Agronomic Importance: Fundamentals and Applications; Alvarez-Venegas, R., De-la-Peña, C., Casas-Mollano, J., Eds.; Springer: Cham, Switzerland, 2019; pp. 311-338.

78. Shen, Y.; Jiang, Z.; Lu, S.; Lin, H.; Gao, S.; Peng, H.; Yuan, G.; Liu, L.; Zhang, Z.; Zhao, M.; et al. Combined small RNA and degradome sequencing reveals microRNA regulation during immature maize embryo dedifferentiation. Biochem. Biophys. Res. Commun. 2013, 441, 425-430. [CrossRef]

79. Zhang, J.; Zhang, S.; Han, S.; Wu, T.; Li, X.; Li, W.; Qi, L. Genome-Wide identification of microRNAs in larch and stage-specific modulation of 11 conserved microRNAs and their targets during somatic embryogenesis. Planta 2012, 236, 647-657. [CrossRef]

80. Hashimoto, K.; Miyashima, S.; Sato-Nara, K.; Yamada, T.; Nakajima, K. Functionally diversified members of the MIR165/6 gene family regulate ovule morphogenesis in Arabidopsis thaliana. Plant Cell Physiol. 2018, 59, 1017-1026. [CrossRef] [PubMed]

81. Swarup, R.; Denyer, T. miRNAs in plant development. Annu. Plant Rev. Online 2019, 2, 1-24.

82. Su, Y.H.; Liu, Y.B.; Zhou, C.; Li, X.M.; Zhang, X.S. The microRNA167 controls somatic embryogenesis in Arabidopsis through regulating its target genes ARF6 and ARF8. Plant Cell Tissue Organ Cult. 2016, 124, 405-417. [CrossRef]

83. Szczygieł-Sommer, A.; Gaj, M.D. The miR396-GRF regulatory module controls the embryogenic response in Arabidopsis via an auxin-related pathway. Int. J. Mol. Sci. 2019, 20, 5221. [CrossRef] [PubMed]

84. Wójcik, A.M.; Mosiolek, M.; Karcz, J.; Nodine, M.D.; Gaj, M.D. Whole mount in situ localization of miRNAs and mRNAs during somatic embryogenesis in Arabidopsis. Front. Plant Sci. 2018, 9, 1-13. [CrossRef]

85. Wójcik, A.M.; Nodine, M.D.; Gaj, M.D. MiR160 and miR166/165 contribute to the LEC2-mediated auxin response involved in the somatic embryogenesis induction in Arabidopsis. Front. Plant Sci. 2017, 8, 1-17. [CrossRef]

86. Lin, Y.; Lin, L.; Lai, R.; Liu, W.; Chen, Y.; Zhang, Z.; XuHan, X.; Lai, Z. MicroRNA390-Directed TAS3 cleavage leads to the production of tasiRNA-ARF3/4 during somatic embryogenesis in Dimocarpus longan Lour. Front. Plant Sci. 2015, 6, 1119. [CrossRef]

87. Li, Z.X.; Li, S.G.; Zhang, L.F.; Han, S.Y.; Li, W.F.; Xu, H.Y.; Yang, W.H.; Liu, Y.I.; Fan, Y.R.; Qi, L.W. Over-Expression of miR166a inhibits cotyledon formation in somatic embryos and promotes lateral root development in seedlings of Larix leptolepis. Plant Cell Tissue Organ Cult. 2016, 127, 461-473. [CrossRef]

88. Li, S.G.; Li, W.F.; Han, S.Y.; Yang, W.H.; Qi, L.W. Stage-Specific regulation of four HD-ZIP III transcription factors during polar pattern formation in Larix leptolepis somatic embryos. Gene 2013, 522, 177-183. [CrossRef] [PubMed]

89. Sanagala, R.; Kumari, R. Expression analysis of miRNA 164c during rice regeneration in different Indica rice genotypes. J. Pure Appl. Microbiol. 2018, 12, 2159-2165. [CrossRef]

90. Sinha, A.; Solanki, M.; Shukla, L.I. Evidences for differential expression of miR167d-5p, target, positional nucleotide preference, and its role in somatic and different stages of regenerating calli of Oryza sativa. Plant Cell Tissue Organ Cult. 2019, 136, 537-548. [CrossRef]

91. Franco-Zorrilla, J.M.; Valli, A.; Todesco, M.; Mateos, I.; Puga, M.I.; Rubio-Somoza, I.; Leyva, A.; Weigel, D.; García, J.A.; Paz-Ares, J. Target mimicry provides a new mechanism for regulation of microRNA activity. Nat. Genet. 2007, 39, 1033-1037. [CrossRef] [PubMed]

92. Tang, X.; Bian, S.; Tang, M.; Lu, Q.; Li, S.; Liu, X.; Tian, G.; Nguyen, V.; Tsang, E.W.T.; Wang, A.; et al. MicroRNA-Mediated repression of the seed maturation program during vegetative development in Arabidopsis. PLoS Genet. 2012, 8, e1003091. [CrossRef]

93. Wójcikowska, B.; Gaj, M.D. Expression profiling of AUXIN RESPONSE FACTOR genes during somatic embryogenesis induction in Arabidopsis. Plant Cell Rep. 2017, 36, 843-858. [CrossRef] 
94. Thibaud-Nissen, F.; Shealy, R.T.; Khanna, A.; Vodkin, L.O. Clustering of microarray data reveals transcript patterns associated with somatic embryogenesis in soybean. Plant Physiol. 2003, 132, 118-136. [CrossRef]

95. Singh, A.; Singh, S.; Panigrahi, K.C.S.; Reski, R.; Sarkar, A.K. Balanced activity of microRNA166/165 and its target transcripts from the class III homeodomain-leucine zipper family regulates root growth in Arabidopsis thaliana. Plant Cell Rep. 2014, 33, 1-9. [CrossRef]

96. Juárez-González, V.T.; López-Ruiz, B.A.; Baldrich, P.; Luján-Soto, E.; Meyers, B.C.; Dinkova, T.D. The explant developmental stage profoundly impacts small RNA-mediated regulation at the dedifferentiation step of maize somatic embryogenesis. Sci. Rep. 2019, 9, 1-14. [CrossRef]

97. Chitwood, D.H.; Nogueira, F.T.S.; Howell, M.D.; Montgomery, T.A.; Carrington, J.C.; Timmermans, M.C.P. Pattern formation via small RNA mobility. Genes Dev. 2009, 23, 549-554. [CrossRef]

98. Guan, C.; Wu, B.; Yu, T.; Wang, Q.; Krogan, N.T.; Liu, X.; Jiao, Y. Spatial auxin signaling controls leaf flattening in Arabidopsis. Curr. Biol. 2017, 27, 2940-2950. [CrossRef] [PubMed]

99. Satterlee, J.W.; Scanlon, M.J. Coordination of leaf development across developmental axes. Plants 2019, 8, 433. [CrossRef] [PubMed]

100. Yoon, E.K.; Yang, J.H.; Lim, J.; Kim, S.H.; Kim, S.K.; Lee, W.S. Auxin regulation of the microRNA390-dependent transacting small interfering RNA pathway in Arabidopsis lateral root development. Nucleic Acids Res. 2009, 38, 1382-1391. [CrossRef] [PubMed]

101. Sugimoto, K.; Jiao, Y.; Meyerowitz, E.M. Arabidopsis regeneration from multiple tissues occurs via a root development pathway. Dev. Cell 2010, 18, 463-471. [CrossRef] [PubMed]

102. Su, Y.H.; Liu, Y.B.; Bai, B.; Zhang, X.S. Establishment of embryonic shoot-root axis is involved in auxin and cytokinin response during Arabidopsis somatic embryogenesis. Front. Plant Sci. 2015, 5, 1-9. [CrossRef] [PubMed]

103. Wang, L.; Chong, K. The essential role of cytokinin signaling in root apical meristem formation during somatic embryogenesis. Front. Plant Sci. 2016, 6, 2015-2017. [CrossRef]

104. Grigg, S.P.; Galinha, C.; Kornet, N.; Canales, C.; Scheres, B.; Tsiantis, M. Repression of apical homeobox genes is required for embryonic root development in Arabidopsis. Curr. Biol. 2009, 19, 1485-1490. [CrossRef]

105. Ding, Z.; Friml, J. Auxin regulates distal stem cell differentiation in Arabidopsis roots. Proc. Natl. Acad. Sci. USA 2010, 107, 12046-12051. [CrossRef]

106. Wang, L.; Liu, N.; Wang, T.; Li, J.; Wen, T.; Yang, X.; Lindsey, K.; Zhang, X. The GhmiR157a-GhSPL10 regulatory module controls initial cellular dedifferentiation and callus proliferation in cotton by modulating ethylene-mediated flavonoid biosynthesis. J. Exp. Bot. 2018, 69, 1081-1093. [CrossRef]

107. Aida, M.; Ishida, T.; Tasaka, M. Shoot apical meristem and cotyledon formation during Arabidopsis embryogenesis: Interaction among the CUP-SHAPED COTYLEDON and SHOOT MERISTEMLESS genes. Development 1999, 126, 1563-1570.

108. Koyama, T.; Furutani, M.; Tasaka, M.; Ohme-Takagi, M. TCP transcription factors control the morphology of shoot lateral organs via negative regulation of the expression of boundary-specific genes in Arabidopsis. Plant Cell 2007, 19, 473-484. [CrossRef]

109. Dastidar, M.G.; Scarpa, A.; Mägele, I.; Ruiz-Duarte, P.; von Born, P.; Bald, L.; Jouannet, V.; Maizel, A. ARF5/MONOPTEROS directly regulates miR390 expression in the Arabidopsis thaliana primary root meristem. Plant Direct 2019, 3, e00116. [CrossRef] [PubMed]

110. Si-Ammour, A.; Windels, D.; Arn-Bouldoires, E.; Kutter, C.; Ailhas, J.; Meins, F.; Vazquez, F. miR393 and secondary siRNAs regulate expression of the TIR1/AFB2 auxin receptor clade and auxin-related development of Arabidopsis leaves. Plant Physiol. 2011, 157, 683-691. [CrossRef] [PubMed]

111. Gray, W.M.; Kepinski, S.; Rouse, D.; Leyser, O.; Estelle, M. Auxin regulates SCF (TIR1)-dependent degradation of AUX/IAA proteins. Nature 2001, 414, 271-276. [CrossRef]

112. Yang, T.; Wang, Y.; Teotia, S.; Wang, Z.; Shi, C.; Sun, H.; Gu, Y.; Zhang, Z.; Tang, G. The interaction between miR160 and miR165/166 in the control of leaf development and drought tolerance in Arabidopsis. Sci. Rep. 2019, 9, 1-13. [CrossRef] [PubMed]

113. Gutierrez, L.; Bussell, J.D.; Păcurar, D.I.; Schwambach, J.; Păcurar, M.; Bellini, C.; Pa, M.; Gutierrez, L.; Bussell, J.D.; Pa, D.I.; et al. Phenotypic plasticity of adventitious rooting in arabidopsis is controlled by complex regulation of AUXIN RESPONSE FACTOR transcripts and microRNA abundance. Plant Cell 2009, 21, 3119-3132. [CrossRef] 
114. Yang, J.H.; Han, S.J.; Yoon, E.K.; Lee, W.S. Evidence of an auxin signal pathway, microRNA167-ARF8-GH3, and its response to exogenous auxin in cultured rice cells. Nucleic Acids Res. 2006, 34, 1892-1899. [CrossRef]

115. Rodriguez, R.E.; Ercoli, M.F.; Debernardi, J.M.; Breakfield, N.W.; Mecchia, M.A.; Sabatini, M.; Cools, T.; De Veylder, L.; Benfey, P.N.; Palatnik, J.F. MicroRNA MIR396 regulates the switch between stem cells and transit-amplifying cells in Arabidopsis roots. Plant Cell 2015, 27, 3354-3366. [CrossRef]

116. Wang, F.; Perry, S.E. Identification of direct targets of FUSCA3, a key regulator of Arabidopsis seed development. Plant Physiol. 2013, 161, 1251-1264. [CrossRef]

117. Kumar, V.; Van Staden, J. New insights into plant somatic embryogenesis: An epigenetic view. Acta Physiol. Plant. 2017, 39, 194-211. [CrossRef]

118. Zheng, Q.; Zheng, Y.; Ji, H.; Burnie, W.; Perry, S.E. Gene regulation by the AGL15 transcription factor reveals hormone interactions in somatic embryogenesis. Plant Physiol. 2016, 172, 2374-2387. [CrossRef] [PubMed]

119. LoSchiavo, F.; Pitto, L.; Giuliano, G.; Torti, G.; Nuti-Ronchi, V.; Marazziti, D.; Vergara, R.; Orselli, S.; Terzi, M. DNA methylation of embryogenic carrot cell cultures and its variations as caused by mutation, differentiation, hormones and hypomethylating drugs. Theor. Appl. Genet. 1989, 77, 325-331. [CrossRef] [PubMed]

120. Leljak-Levanić, D.; Mihaljević, S.; Jelaska, S. Variations in DNA methylation in Picea omorika (Panč) Purk. embryogenic tissue and the ability for embryo maturation. Propag. Ornam. Plants 2009, 9, 3-9.

121. Huang, H.; Han, S.S.; Wang, Y.; Zhang, X.Z.; Han, Z.H. Variations in leaf morphology and DNA methylation following in vitro culture of Malus xiaojinensis. Plant Cell Tissue Organ Cult. 2012, 111, 153-161. [CrossRef]

122. Ji, L.; Mathioni, S.M.; Johnson, S.; Tucker, D.; Bewick, A.J.; Do Kim, K.; Daron, J.; Slotkin, R.K.; Jackson, S.A.; Parrott, W.A.; et al. Genome-Wide reinforcement of DNA methylation occurs during somatic embryogenesis in soybean. Plant Cell 2019, 31, 2315-2331. [CrossRef] [PubMed]

123. Sugimoto, K.; Temman, H.; Kadokura, S.; Matsunaga, S. To regenerate or not to regenerate: Factors that drive plant regeneration. Curr. Opin. Plant Biol. 2019, 47, 138-150. [CrossRef]

124. Vining, K.; Pomraning, K.R.; Wilhelm, L.J.; Ma, C.; Pellegrini, M.; Di, Y.; Mockler, T.C.; Freitag, M.; Strauss, S.H. Methylome reorganization during in vitro dedifferentiation and regeneration of Populus trichocarpa. BMC Plant Biol. 2013, 13, 92. [CrossRef]

125. Wickramasuriya, A.M.; Dunwell, J.M. Global scale transcriptome analysis of Arabidopsis embryogenesis in vitro. BMC Genom. 2015, 16, 301. [CrossRef]

126. Li, J.; Wang, M.; Li, Y.; Zhang, Q.; Lindsey, K.; Daniell, H.; Jin, S.; Zhang, X.; Kingdom, U. Multi-Omics analyses reveal epigenomics basis for cotton somatic embryogenesis through successive regeneration acclimation process. Plant Biotechnol. J. 2019, 17, 435-450. [CrossRef]

127. Ashapkin, V.V.; Kutueva, L.I.; Aleksandrushkina, N.I.; Vanyushin, B.F. Epigenetic regulation of plant gametophyte development. Int. J. Mol. Sci. 2019, 20, 3051. [CrossRef]

128. Yamamoto, N.; Kobayashi, H.; Togashi, T.; Mori, Y.; Kikuchi, K.; Kuriyama, K.; Tokuji, Y. Formation of embryogenic cell clumps from carrot epidermal cells is suppressed by 5-azacytidine, a DNA methylation inhibitor. J. Plant Physiol. 2005, 162, 47-54. [CrossRef] [PubMed]

129. Jiang, F.; Xu, X.; Liu, H.; Zhu, J. DRM1 and DRM2 are involved in Arabidopsis callus formation. Plant Cell Tissue Organ Cult. 2015, 123, 221-228. [CrossRef]

130. Liao, W.W.; Yen, M.R.; Ju, E.; Hsu, F.M.; Lam, L.; Chen, P.Y. MethGo: A comprehensive tool for analyzing whole-genome bisulfite sequencing data. BMC Genom. 2015, 16, S11. [CrossRef] [PubMed]

131. Li, W.; Liu, H.; Cheng, Z.J.; Su, Y.H.; Han, H.N.; Zhang, Y.; Zhang, X.S. DNA methylation and histone modifications regulate de novo shoot regeneration in Arabidopsis by modulating WUSHEL expression and auxin signaling. PLoS Genet. 2011, 7, e1002243. [CrossRef] [PubMed]

132. Xiao, W.; Custard, R.D.; Brown, R.C.; Lemmon, B.E.; Harada, J.J.; Goldberg, R.B.; Fischer, R.L. DNA methylation is critical for Arabidopsis embryogenesis and seed viability. Plant Cell 2006, 18, 805-814. [CrossRef]

133. Su, Y.H.; Zhao, X.Y.; Liu, Y.B.; Zhang, C.L.; O'Neill, S.D.; Zhang, X.S. Auxin-Induced WUS expression is essential for embryonic stem cell renewal during somatic embryogenesis in Arabidopsis. Plant J. 2009, 59, 448-460. [CrossRef]

134. Fraga, H.P.F.; Vieira, L.N.; Heringer, A.S.; Puttkammer, C.C.; Silveira, V.; Guerra, M.P. DNA methylation and proteome profiles of Araucaria angustifolia (Bertol.) Kuntze embryogenic cultures as affected by plant growth regulators supplementation. Plant Cell Tissue Organ Cult. 2016, 125, 353-374. [CrossRef]

135. Hsieh, T.F.; Ibarra, C.A.; Silva, P.; Zemach, A.; Eshed-Williams, L.; Fischer, R.L.; Zilberman, D. Genome-Wide demethylation of Arabidopsis endosperm. Science 2009, 324, 1451-1454. [CrossRef] 
136. Teerawanichpan, P.; Krittanai, P.; Chauvatcharin, N.; Narangajavana, J. Purification and characterization of rice DNA methyltransferase. Plant Physiol. Biochem. 2009, 47, 671-680. [CrossRef]

137. Penterman, J.; Zilberman, D.; Huh, J.H.; Ballinger, T.; Henikoff, S.; Fischer, R.L. DNA demethylation in the Arabidopsis genome. Proc. Natl. Acad. Sci. USA 2007, 104, 6752-6757. [CrossRef]

138. Elhiti, M.; Tahir, M.; Gulden, R.H.; Khamiss, K.; Stasolla, C. Modulation of embryo-forming capacity in culture through the expression of Brassica genes involved in the regulation of the shoot apical meristem. J. Exp. Bot. 2010, 61, 4069-4085. [CrossRef] [PubMed]

139. Chakrabarty, D.; Yu, K.W.; Paek, K.Y. Detection of DNA methylation changes during somatic embryogenesis of Siberian ginseng (Eleuterococcus senticosus). Plant Sci. 2003, 165, 61-68. [CrossRef]

140. Quinga, L.A.P.; Fraga, H.P.F.; Vieira, L.N.; Guerra, M.P. Epigenetics of long-term somatic embryogenesis in Theobroma cacao L.: DNA methylation and recovery of embryogenic potential. Plant Cell Tissue Organ Cult. 2017, 131, 295-305. [CrossRef]

141. Fraga, H.P.F.; Vieira, L.N.; Caprestano, C.A.; Steinmacher, D.A.; Micke, G.A.; Spudeit, D.A.; Pescador, R.; Guerra, M.P. 5-Azacytidine combined with 2,4-D improves somatic embryogenesis of Acca sellowiana (O. Berg) Burret by means of changes in global DNA methylation levels. Plant Cell Rep. 2012, 31, 2165-2176. [CrossRef] [PubMed]

142. Shibukawa, T.; Yazawa, K.; Kikuchi, A.; Kamada, H. Possible involvement of DNA methylation on expression regulation of carrot LEC1 gene in its 5'-upstream region. Gene 2009, 437, 22-31. [CrossRef] [PubMed]

143. Shemer, O.; Landau, U.; Candela, H.; Zemach, A.; Williams, L.E. Competency for shoot regeneration from Arabidopsis root explants is regulated by DNA methylation. Plant Sci. 2015, 238, 251-261. [CrossRef]

144. Karim, R.; Tan, Y.S.; Singh, P.; Nuruzzaman, M.; Khalid, N.; Harikrishna, J.A. Expression and DNA methylation of MET1, CMT3 and DRM2 during in vitro culture of Boesenbergia rotunda (L.) Mansf. Philipp. Agric. Sci. 2018, 101, 261-270.

145. Niederhuth, C.E.; Schmitz, R.J. Putting DNA methylation in context: From genomes to gene expression in plants. Biochim. Biophys. Acta Gene Regul. Mech. 2017, 1860, 149-156. [CrossRef]

146. Chwialkowska, K.; Nowakowska, U.; Mroziewicz, A.; Szarejko, I.; Kwasniewski, M. Water-Deficiency conditions differently modulate the methylome of roots and leaves in barley (Hordeum vulgare L.). J. Exp. Bot. 2016, 67, 1109-1121. [CrossRef]

147. Grafi, G.; Zemach, A.; Pitto, L. Methyl-CpG-Binding domain (MBD) proteins in plants. Biochim. Biophys. Acta Gene Struct. Expr. 2007, 1769, 287-294. [CrossRef]

148. Bouyer, D.; Roudier, F.; Heese, M.; Andersen, E.D.; Gey, D.; Nowack, M.K.; Goodrich, J.; Renou, J.P.; Grini, P.E.; Colot, V.; et al. Polycomb repressive complex 2 controls the embryo-to-seedling phase transition. PLoS Genet. 2011, 7, e1002014. [CrossRef]

149. Nic-Can, G.I.; López-Torres, A.; Barredo-Pool, F.; Wrobel, K.; Loyola-Vargas, V.M.; Rojas-Herrera, R.; De-la-Peña, C. New insights into somatic embryogenesis: LEAFY COTYLEDON1, BABY BOOM1 and WUSCHEL-RELATED HOMEOBOX4 are epigenetically regulated in Coffea canephora. PLoS ONE 2013, 8, e72160. [CrossRef]

150. Ikeuchi, M.; Iwase, A.; Rymen, B.; Harashima, H.; Shibata, M.; Ohnuma, M.; Breuer, C.; Morao, A.K.; De Lucas, M.; De Veylder, L.; et al. PRC2 represses dedifferentiation of mature somatic cells in Arabidopsis. Nat. Plants 2015, 1, 1-7. [CrossRef] [PubMed]

151. Orłowska, A.; Igielski, R.; Łagowska, K.; Kępczyńska, E. Identification of LEC1, L1L and Polycomb Repressive Complex 2 genes and their expression during the induction phase of Medicago truncatula Gaertn. somatic embryogenesis. Plant Cell Tissue Organ Cult. 2017, 129, 119-132. [CrossRef]

152. Rose, R.J. Somatic embryogenesis in the Medicago truncatula model: Cellular and molecular mechanisms. Front. Plant Sci. 2019, 10, 267. [CrossRef] [PubMed]

153. Wójcikowska, B.; Jaskóła, K.; Gąsiorek, P.; Meus, M.; Nowak, K.; Gaj, M.D. LEAFY COTYLEDON2 (LEC2) promotes embryogenic induction in somatic tissues of Arabidopsis, via YUCCA-mediated auxin biosynthesis. Planta 2013, 238, 425-440. [CrossRef]

154. Figueiredo, D.D.; Batista, R.A.; Roszak, P.J.; Köhler, C. Auxin production couples endosperm development to fertilization. Nat. Plants 2015, 1, 1-6. [CrossRef]

155. He, C.; Chen, X.; Huang, H.; Xu, L. Reprogramming of H3K27me3 is critical for acquisition of pluripotency from cultured Arabidopsis tissues. PLoS Genet. 2012, 8, e1002911. [CrossRef] 
156. Gu, X.; Xu, T.; He, Y. A Histone H3 lysine-27 methyltransferase complex represses lateral root formation in Arabidopsis thaliana. Mol. Plant 2014, 7,977-988. [CrossRef]

157. Tang, L.P.; Zhou, C.; Wang, S.S.; Yuan, J.; Zhang, X.S.; Su, Y.H. FUSCA3 interacting with LEAFY COTYLEDON2 controls lateral root formation through regulating YUCCA4 gene expression in Arabidopsis thaliana. New Phytol. 2017, 213, 1740-1754. [CrossRef]

158. Tsukagoshi, H.; Morikami, A.; Nakamura, K. Two B3 domain transcriptional repressors prevent sugarinducible expression of seed maturation genes in Arabidopsis seedlings. Proc. Natl. Acad. Sci. USA 2007, 104, 2543-2547. [CrossRef] [PubMed]

159. Yang, C.; Bratzel, F.; Hohmann, N.; Koch, M.; Turck, F.; Calonje, M. VAL-and AtBMI1-mediated H2Aub initiate the switch from embryonic to postgerminative growth in Arabidopsis. Curr. Biol. 2013, 23, 1324-1329. [CrossRef]

160. Kingston, R.E.; Tamkun, J.W. Transcriptional regulation by trithorax-group proteins. Cold Spring Harb. Perspect. Biol. 2014, 6, 1-18. [CrossRef] [PubMed]

161. Fletcher, J.C. State of the art: TrxG factor regulation of post-embryonic plant development. Front. Plant Sci. 2017, 8, 1-8. [CrossRef]

162. Ariel, F.; Jegu, T.; Latrasse, D.; Romero-Barrios, N.; Christ, A.; Benhamed, M.; Crespi, M. Noncoding transcription by alternative RNA polymerases dynamically regulates an auxin-driven chromatin loop. Mol. Cell 2014, 55, 383-396. [CrossRef] [PubMed]

163. Wu, M.F.; Yamaguchi, N.; Xiao, J.; Bargmann, B.; Estelle, M.; Sang, Y.; Wagner, D. Auxin-Regulated chromatin switch directs acquisition of flower primordium founder fate. eLife 2015, 4, 1-20. [CrossRef]

164. Yang, S.; Li, C.; Zhao, L.; Gao, S.; Lu, J.; Zhao, M.; Chen, C.Y.; Liu, X.; Luo, M.; Cui, Y.; et al. The Arabidopsis SWI2/SNF2 chromatin remodeling ATPase BRAHMA targets directly to PINs and is required for root stem cell niche maintenance. Plant Cell 2015, 27, 1670-1680. [CrossRef]

165. Li, C.; Gu, L.; Gao, L.; Chen, C.; Wei, C.Q.; Qiu, Q.; Chien, C.W.; Wang, S.; Jiang, L.; Ai, L.F.; et al. Concerted genomic targeting of H3K27 demethylase REF6 and chromatin-remodeling ATPase BRM in Arabidopsis. Nat. Genet. 2016, 48, 687-693. [CrossRef]

166. Weiste, C.; Dröge-Laser, W. The Arabidopsis transcription factor BZIP11 activates auxin-mediated transcription by recruiting the histone acetylation machinery. Nat. Commun. 2014, 5, 1-12. [CrossRef]

167. Rodríguez-Sanz, H.; Moreno-Romero, J.; Solís, M.T.; Köhler, C.; Risueño, M.C.; Testillano, P.S. Changes in histone methylation and acetylation during microspore reprogramming to embryogenesis occur concomitantly with bnHKMT and BnHAT expression and are associated with cell totipotency, proliferation, and differentiation in Brassica napus. Cytogenet. Genome Res. 2014, 143, 209-218. [CrossRef]

168. Pérez, M.; Cañal, M.J.; Toorop, P.E. Expression analysis of epigenetic and abscisic acid-related genes during maturation of Quercus suber somatic embryos. Plant Cell Tissue Organ Cult. 2015, 121, 353-366. [CrossRef]

169. Yakovlev, I.A.; Carneros, E.; Lee, Y.K.; Olsen, J.E.; Fossdal, C.G. Transcriptional profiling of epigenetic regulators in somatic embryos during temperature induced formation of an epigenetic memory in Norway spruce. Planta 2016, 243, 1237-1249. [CrossRef] [PubMed]

170. Zhou, Y.; Tan, B.; Luo, M.; Li, Y.; Liu, C.; Chen, C.; Yu, C.W.; Yang, S.; Dong, S.; Ruan, J.; et al. HISTONE DEACETYLASE19 interacts with HSL1 and participates in the repression of seed maturation genes in Arabidopsis seedlings. Plant Cell 2013, 25, 134-148. [CrossRef] [PubMed]

171. Chhun, T.; Chong, S.Y.; Park, B.S.; Wong, E.C.C.; Yin, J.L.; Kim, M.; Chua, N.H. HSI2 repressor recruits MED13 and HDA6 to down-regulate seed maturation gene expression directly during Arabidopsis early seedling growth. Plant Cell Physiol. 2016, 57, 1689-1706. [CrossRef]

172. Horstman, A.; Bemer, M.; Boutilier, K. A transcriptional view on somatic embryogenesis. Regeneration 2017, 4, 201-216. [CrossRef]

173. Williams, L.; Zhao, J.; Morozova, N.; Li, Y.; Avivi, Y.; Grafi, G. Chromatin reorganization accompanying cellular dedifferentiation is associated with modifications of histone $\mathrm{H} 3$, redistribution of HP1, and activation of E2F-target genes. Dev. Dyn. 2003, 228, 113-120. [CrossRef]

174. Jung, M.; Hoffmann, K.; Brosch, G.; Loidl, P. Analogues of trichostatin A and trapoxin B as histone deacetylase inhibitors. Bioorg. Med. Chem. Lett. 1997, 7, 1655-1658. [CrossRef]

175. Görisch, S.M.; Wachsmuth, M.; Tóth, K.F.; Lichter, P.; Rippe, K. Histone acetylation increases chromatin accessibility. J. Cell Sci. 2005, 118, 5825-5834. [CrossRef] 
176. Venturelli, S.; Belz, R.G.; Kämper, A.; Berger, A.; Von Horn, K.; Wegner, A.; Böcker, A.; Zabulon, G.; Langenecker, T.; Kohlbacher, O.; et al. Plants release precursors of histone deacetylase inhibitors to suppress growth of competitors. Plant Cell 2015, 27, 3175-3189. [CrossRef]

177. Mengel, A.; Ageeva, A.; Georgii, E.; Bernhardt, J.; Wu, K.; Durner, J.; Lindermayr, C. Nitric oxide modulates histone acetylation at stress genes by inhibition of histone deacetylases1. Plant Physiol. 2017, 173, 1434-1452. [CrossRef]

178. Uddenberg, D.; Valladares, S.; Abrahamsson, M.; Sundström, J.F.; Sundås-Larsson, A.; von Arnold, S. Embryogenic potential and expression of embryogenesis-related genes in conifers are affected by treatment with a histone deacetylase inhibitor. Planta 2011, 234, 527-539. [CrossRef] [PubMed]

179. Abrahamsson, M.; Valladares, S.; Merino, I.; Larsson, E.; von Arnold, S. Degeneration pattern in somatic embryos of Pinus sylvestris L. In Vitro Cell. Dev. Biol. Plant 2017, 53, 86-96. [CrossRef] [PubMed]

180. Jiang, F.; Ryabova, D.; Diedhiou, J.; Hucl, P.; Randhawa, H.; Marillia, E.F.; Foroud, N.A.; Eudes, F.; Kathiria, P. Trichostatin A increases embryo and green plant regeneration in wheat. Plant Cell Rep. 2017, 36, 1701-1706. [CrossRef] [PubMed]

181. Li, H.; Soriano, M.; Cordewener, J.; Muiño, J.M.; Riksen, T.; Fukuok, H.; Angenent, G.C.; Boutilier, K. The histone deacetylase inhibitor trichostatin a promotes totipotency in the male gametophyte. Plant Cell 2014, 26, 195-209. [CrossRef]

182. Jia, H.; Suzuki, M.; Mccarty, D.R. Regulation of the seed to seedling developmental phase transition by the LAFL and VAL transcription factor networks. Wiley Interdiscip. Rev. Dev. Biol. 2014, 3, 135-145. [CrossRef]

183. Inoue, K.; Oikawa, M.; Kamimura, S.; Ogonuki, N.; Nakamura, T.; Nakano, T.; Abe, K.; Ogura, A. Trichostatin A specifically improves the aberrant expression of transcription factor genes in embryos produced by somatic cell nuclear transfer. Sci. Rep. 2015, 5, 1-12. [CrossRef]

184. Mackmull, M.; Iskar, M.; Parca, L.; Singer, S.; Bork, P.; Ori, A.; Beck, M.; Hdacs, H. Histone deacetylase inhibitors (HDACi) cause the selective depletion of bromodomain containing proteins (BCPs). Mol. Cell. Proteom. 2015, 14, 1350-1360. [CrossRef]

185. Lai, X.; Verhage, L.; Hugouvieux, V.; Zubieta, C. Pioneer factors in animals and plants-colonizing chromatin for gene regulation. Molecules 2018, 23, 1914. [CrossRef]

186. Dolfini, D.; Gatta, R.; Mantovani, R. NF-Y and the transcriptional activation of CCAAT promoters. Crit. Rev. Biochem. Mol. Biol. 2012, 47, 29-49. [CrossRef]

187. Ueno, Y.; Ishikawa, T.; Watanabe, K.; Terakura, S.; Iwakawa, H.; Okada, K.; Machida, C.; Machida, Y. Histone deacetylases and asymmetric leaves 2 are involved in the establishment of polarity in leaves of Arabidopsis. Plant Cell 2007, 19, 445-457. [CrossRef]

188. Kim, W.; Benhamed, M.; Servet, C.; Latrasse, D.; Zhang, W.; Delarue, M.; Zhou, D.X. Histone acetyltransferase GCN5 interferes with the miRNA pathway in Arabidopsis. Cell Res. 2009, 19, 899-909. [CrossRef] [PubMed]

189. Meng, Y.; Shao, C.; Wang, H.; Chen, M. The regulatory activities of plant microRNAs: A more dynamic perspective. Plant Physiol. 2011, 157, 1583-1595. [CrossRef]

190. de Brot, S.; Rutland, C.S.; Mongan, N.P.; James, V. Epigenetic control of microRNA expression and cancer. In Translational Epigenetics, Cancer and Noncoding RNAs; Chakrabarti, J., Mitra, S., Eds.; Elsevier Academic Press: Cambridge, MA, USA, 2018; pp. 373-380.

191. Ou, J.N.; Torrisani, J.; Unterberger, A.; Provençal, N.; Shikimi, K.; Karimi, M.; Ekström, T.J.; Szyf, M. Histone deacetylase inhibitor Trichostatin A induces global and gene-specific DNA demethylation in human cancer cell lines. Biochem. Pharmacol. 2007, 73, 1297-1307. [CrossRef] [PubMed]

192. Yang, F.; Zhang, L.; Li, J.; Huang, J.; Wen, R.; Ma, L.; Zhou, D.; Li, L. Trichostatin A and 5-azacytidine both cause an increase in global histone $\mathrm{H} 4$ acetylation and a decrease in global DNA and H3K9 methylation during mitosis in maize. BMC Plant Biol. 2010, 10, 178. [CrossRef] [PubMed]

193. Hofmann, F.; Schon, M.A.; Nodine, M.D. The embryonic transcriptome of Arabidopsis thaliana. Plant Reprod. 2019, 32, 77-91. [CrossRef] [PubMed]

194. Gao, P.; Xiang, D.; Quilichini, T.D.; Venglat, P.; Pandey, P.K.; Wang, E.; Gillmor, C.S.; Datla, R. Gene expression atlas of embryo development in Arabidopsis. Plant Reprod. 2019, 32, 93-104. [CrossRef]

195. Stone, S.L.; Braybrook, S.A.; Paula, S.L.; Kwong, L.W.; Meuser, J.; Pelletier, J.; Hsieh, T.F.F.; Fischer, R.L.; Goldberg, R.B.; Harada, J.J. Arabidopsis LEAFY COTYLEDON2 induces maturation traits and auxin activity: Implications for somatic embryogenesis. Proc. Natl. Acad. Sci. USA 2008, 105, 3151-3156. [CrossRef] 
196. Junker, A.; Mönke, G.; Rutten, T.; Keilwagen, J.; Seifert, M.; Thi, T.M.N.; Renou, J.P.; Balzergue, S.; Viehöver, P.; Hähnel, U.; et al. Elongation-Related functions of LEAFY COTYLEDON1 during the development of Arabidopsis thaliana. Plant J. 2012, 71, 427-442. [CrossRef]

197. Kagaya, Y.; Toyoshima, R.; Okuda, R.; Usui, H.; Yamamoto, A.; Hattori, T. LEAFY COTYLEDON1 controls seed storage protein genes through its regulation of FUSCA3 and ABSCISIC ACID INSENSITIVE3. Plant Cell Physiol. 2005, 46, 399-406. [CrossRef]

198. Dinesh, D.C.; Villalobos, L.I.A.C.; Abel, S. Structural biology of nuclear auxin action. Trends Plant Sci. 2016, 21, 302-316. [CrossRef]

199. Ledwoń, A.; Gaj, M.D. LEAFY COTYLEDON2 gene expression and auxin treatment in relation to embryogenic capacity of Arabidopsis somatic cells. Plant Cell Rep. 2009, 28, 1677-1688. [CrossRef] [PubMed]

200. Ledwoń, A.; Gaj, M.D. LEAFY COTYLEDON1, FUSCA3 expression and auxin treatment in relation to somatic embryogenesis induction in Arabidopsis. Plant Growth Regul. 2011, 65, 157-167. [CrossRef]

201. Horstman, A.; Li, M.; Heidmann, I.; Weemen, M.; Chen, B.; Muino, J.M.; Angenent, G.C.; Boutilier, K. The BABY BOOM transcription factor activates the LEC1-ABI3-FUS3-LEC2 network to induce somatic embryogenesis. Plant Physiol. 2017, 175, 848-857. [CrossRef] [PubMed]

(C) 2020 by the authors. Licensee MDPI, Basel, Switzerland. This article is an open access article distributed under the terms and conditions of the Creative Commons Attribution (CC BY) license (http://creativecommons.org/licenses/by/4.0/). 